\title{
Fiestas, borracheras y rebeliones (Introducción y transcripción del expediente de averiguación del tumulto acaecido en Ingaguasi, 1777) ${ }^{1}$
}

Nelson Castro F. ${ }^{2}$, Jorge Hidalgo L. ${ }^{3}$ y Viviana Briones V. ${ }^{4}$

\section{RESUMEN}

Este artículo consta de una introducción y de la transcripción del expediente de la rebelión acontecida en Ingaguasi en 1775 (jurisdicción de la provincia de Atacama). En la introducción se discute la relación entre fiestas, borracheras y rebeliones considerando que en ellas se encuentra un ámbito de manifestaciones de las autonomías subalternas. Señalando, además, que las disposiciones reales tendientes a restringir la realización de fiestas y borracheras forman parte de una ofensiva central por recuperar el control sobre las poblaciones indígenas.

Palabras claves: Fiestas - borracheras - rebeliones Ingaguasi - San Pedro.

\section{ABSTRACT}

This article includes an introduction and the transcription of an inquest for rebellion against Ingaguasi in 1775 (Atacama Province jurisdiction). The introduction explores the relationships between fiestas, drunkenness and rebellion by considering how these form fields of expression for the subaltern autonomies. We also note that the colonial arrangements tending to restrict fiestas and drunkenness formed part of a central offensive to recover the control over indigenous populations.

Key words: Fiestas - drunkeness - rebellion - Ingaguasi San Pedro.

Recibido: febrero 2003. Manuscrito revisado aceptado: septiembre 2003.

\section{Introducción}

Hacia la segunda mitad del siglo XVIII, un fallido connato de rebelión indígena afectó a la capi-

1 Este trabajo forma parte del Proyecto FONDECYT 1000089: "Historia de los pueblos andinos de Arica, Tarapacá y Atacama: Control político, memoria y resistencia étnicas. Siglos XVI-XIX”, cuyo investigador responsable es Jorge Hidalgo.

2 Universidad de Valparaíso. 1 Oriente $\mathrm{N}^{\circ} 41$, Viña del Mar. Email: nelson.castro@uv.cl

3 Universidad de Chile. Diagonal Paraguay 1285, Oficina 803, Santiago. Email: hidalgol@uch.cl

4 Email: humagata@yahoo.es tal del Virreinato del Perú. De acuerdo a la Memoria del saliente virrey José Antonio Manso de Velasco, los "regocijos y festividades", en la que los indios habían estado expuestos a la "embriaguez", habían sido los lugares de la "maquinación" y el reclutamiento de confabuladores, por lo que precisó:

"que se observen con disimulo, como lo he practicado por medio de ministros de cordura, y mas los dias de regocijos y festividades que estan muy expuestos á la embriaguez y juntas, pues en las que tubieron por espacio de dos años en diversos y retirados sitios, alentaron su maquinacion y le aumentaron sus cómplices" (Memorias, t. 4, 1856: 98).

Esta maquinación se había visto favorecida por la presencia de un crecido número de indios que se habían instalado, en la capital del virreinato, ya sea para trabajar en oficios mecánicos o porque se hallaban transplantados desde hacía tiempo. La memoria del virrey entregaba detalles sobre quienes participaron en este connato de rebelión y sobre la dimensión que tuvo el tumulto protagonizados por los indígenas. Hay un hecho que nos interesa resaltar del informe del virrey. De acuerdo a este, la confabulación había ido adquiriendo cuerpo, durante dos años, en "los días de regocijos y festividades" en los que los confabuladores estaban "expuestos á la embriaguez y juntas".

Sobre esto último, una cuestión, tal vez irrelevante: ¿Por qué el virrey prefirió embriaguez a borrachera? Más aún, si esta última denominación sigue utilizándose en varios documentos, a lo largo del siglo XVIII, incluidos los que mencionaremos más adelante. Sin pretender contrariar lo desarrollado por Soledad González (2002) en su trabajo sobre embriaguez y pecado, ni de desconocer la vinculación que esta tiene con un grille teológico-moral, sostenemos que el uso de "embriaguez" no es arbitrario si se examina en relación 
con la configuración de una nueva racionalidad del control político, desde la segunda mitad del siglo XVIII, que comienza a afectar a la metrópoli y a los representantes del poder real. Racionalización del control político que se va desplazando, precisamente a partir de este período, desde el paradigma de la cristianización al paradigma de la civilización (Gruzinski 1993). Proceso que no va estar exento de disputas y de conflictos, sobre todo entre intelectuales afanados en influir en la determinación de un nuevo bloque hegemónico, el que se mantuvo, siguiendo la definición gramsciana, como contradictorio. Una disputa descrita por González Casanova (1948) hace ya varias décadas, entre las tendencias misoneístas y las que apostaban por una modernidad cristiana, reticentes ambas a asumir el excesivo racionalismo de las Luces, por cuanto corroía los fundamentos ontológicos que legitimaban el dualismo de la Majestad Real. Precisamente, esto ayuda a entender que la teología siguiera proveyendo los fundamentos a la ontología de la cual se derivaba la legitimidad y la soberanía del poder real. No obstante, el desplazamiento de la cristianización a la civilización indicaba el énfasis en una cierta autonomía de la racionalidad política. Como lo ha observado De Certeau (1993), para la Francia del siglo XVII, en un fenómeno que comenzará a afectar a la Península en la segunda mitad del siglo XVIII, la "razón de estado" comenzará a imponerse sobre las antiguas referencias religiosas. Las fiestas, regocijos y la embriaguez eran censurables en tanto estaban vinculados con actos políticos que cuestionaban el orden en el cuerpo social, porque sus excesivos gastos impedían el fomento de las poblaciones y su felicidad material, y no tanto por la proximidad que estas guardaban con el vicio o el pecado.

\section{Sobre borracheras y convites: La antieconomía de la fiesta}

En una sociedad preocupada por aumentar los ingresos de la Corona, el crecimiento espiritual y material de las poblaciones, para alejarlas de los vestigios de la barbarie y de la gentilidad; las fiestas, con sus gastos excesivos y los vicios que las acompañaban, aparecían como el espacio de la antieconomía del poder. Ese ataque a las fiestas persiguió el doble propósito de minar la influencia del clero entre las comunidades y restringir el espacio de aquellas expresiones que contribuían más fuertemente a generar un cierto sentido de pertenencia comunitaria:
"Los Curas cargan a los Yndios con muchas fiestas nombrandolos Maiordomos y Alferes de ellas: que no essta su maior daño en los Derechos que pagan porque son ... insoportables gastos que hasen con esste motibo pues combidando a todos los vessinos del pueblo por dos o tres dias á comer y beber embriagandose todos siguiendose de essto los males que se dejan considerar y que aunque los Corregidores y Curas han procurado siempre desarraigar essta permissiona corruptela nunca han podido conseguirlo por rreisarlo [sic] los Yndios con pretexto de que no quieren ser menos que sus antesesores que hacian lo mismo" (AGI, Charcas, 498, 1774, s/f).

Estamos en presencia de una modalidad colonial de fiesta comunitaria, la fiesta-cargo, vinculada a la mantención del prestigio de quienes actuaban como mayordomos o alféreces de las mismas, acrecentando, además, el de sus antecesores. En dichas actividades, los mayordomos incurrían en abusos de funciones de iglesia. Y no sólo eran estas fiestas, desarrolladas con motivo del día del santo patrono de alguna localidad, sino que todos aquellos convites que se acostumbraban realizar con motivo de casamientos, bautismos y misas nuevas, en los que los indios se entregaban a la embriaguez, los que debían restringirse:

"Los corregidores de las Provinsias tengan particular cuidado de que los Yndios en sus fiestas y conbites se abstengan de Embriagarse sin permitirles hagan combites cosstosos y de concurrensia de mucha Jente, pues solamente podran combidar a sus Parientes parientas y afines dentro del tersser grado y seis Personas extrañas sin que de este numero se puedan exseder con pretexto alguno, y a los que contrabinieren se les impondra el corresspondiente casstigo por dichos corregidores sobre lo qual tendran particular cuidado los cassiquez, Gobernadores, Ylacatas y Alcaldes sin permitir que los Yndios se embriaguen y que en sus fiestas los combidados no ssean otros que las Personas ya expresadas" (AGI, Charcas, 498, 1774 , s/f).

Este ataque contra las costumbres se legitimaba por cuanto sus abusos y excesos introducían, en el cuerpo social, distorsiones que el poder no estaba dispuesto a amparar. Un punto que llama la atención es el de la restricción del número de participantes en los convites. Al parecer se trata 
de una celosa racionalización de las relaciones y de los gastos en los que incurrían los indígenas. Pero hay una otra situación que no puede ser descuidada. Desde la segunda mitad del siglo XVIII, se promulgó una serie de medidas tendientes a transformar el Imperio Español, de manera de permitir un mejor control y de ajustar las dinámicas provinciales a los intereses del poder central. En otras tantas situaciones, se observaba con bastante inquietud la proliferación de prácticas que estorbaban la civilización y que permitían la reproducción de la barbarie. Gruzinski (1993) ha señalado que esta segunda aculturación, que tuvo alcances sin precedentes, golpeó fuertemente a las culturas populares y, particularmente, a las culturas indígenas. Los esfuerzos tendieron a reorientar y a extremar la supervisión de los indígenas, sobre todo en lo relacionado con su "felicidad material". Se consideraba que los hombres eran el origen de la riqueza y de la fuerza del estado, de los que dependía la felicidad natural y política. En ese sentido, se trataba de hacer industrioso al indio en beneficio propio y del estado (Memorias, 1859, tomo VI: 70-73). Esta preocupación entraba en pugna con las formas y los mecanismos de solidaridad-prestigio comunitarios, que habían manipulado las fiestas diseñadas para lograr una más adecuada cristianización de las poblaciones indígenas, y que generaban un cierto espacio de autonomía que aparecía intolerable para un poder dispuesto a lograr un más eficiente control político.

Las fiestas no sólo representaban un gasto excesivo de recursos, que se distraían innecesariamente, sino que en ellas, y esto era preocupante, se ocasionaban mayores males como los que surgían de los abusos y excesos de la embriaguez. Esta preocupación, materializada en el ataque contra las costumbres, deja entrever esa desconfianza postridentina que invadió a las élites europeas, contra las fiestas, con su predominio de gritos y gestos blasfemos, que solían terminar en "orgía y violencia" (Davis 1993; Mandrou 1962). Este ataque a las costumbres, particularmente de aquellas que se desarrollaban al margen de las normas proclamadas, formó parte de una "normalización vigilante" que intentó "hacer entrar, en el marco religioso y moral de una cristiandad austera, a poblaciones que con demasiada frecuencia eran refractarias a este orden estricto" (Delumeau 2002: 618). Se trata de cambiar "actitudes y valores", introduciendo a ese amplio sector de la población, en las normas de vida propias de los grupos "cultivados"; normas que se oponían a la "rusticidad" y "barbarie" de los grupos subalternos (Fontana 2002: 98). Pero esa "voluntad de acultura-ción" de las élites europeas, que describe ampliamente Delumeau, fue articulada desde una cierta concepción de la policía cristiana y civil, bajo el predominio de las referencias religiosas, coincidiendo significativamente, como lo ha señalado Ginsburg (1997), con el surgimiento de procesos de modernización socioeconómica (en los que destaca el agravamiento de las diferencias sociales impulsado por el predominio de las economías monetarias) o, si se prefiere, de racionalización de las relaciones sociales, que no se se pudieron comprender, a la larga, mostrando su agotamiento, a partir de las viejas referencias religiosas.

Ahora bien, la voluntad de aculturación, que predomina entre las élites europeas desde el siglo XVI, resurgirá, durante la segunda mitad del siglo XVIII, privilegiando antes que las referencias religiosas la preeminencia de la "policía civil" y la "felicidad material" de las poblaciones. Las fiestas debían ser especialmente vigiladas, porque implicaban un desgaste innecesario de recursos y, sobre todo, porque daban cabida a expresiones de inversión y a lenguajes subversivos (Hidalgo y Castro 1997 y 1999; Vovelle 1985). Una cuestión sobre la que el virrey Manso de Velasco había llamado la atención respecto del levantamiento del Cuzco: las juntas y convites de los indios les habían permitido a los instigadores dar movimiento a su maquinación y aumentar a los confabuladores.

\section{El ataque a los modos de expresión}

Hacia la década de 1770, el corregidor Francisco de Argumaniz inició una sostenida campaña por cambiar el paisaje de la "mísera provincia" de Atacama, siguiendo el patrón de civilización elaborado por el poder central, y según el cual se posibilitaba la "felicidad material" de las poblaciones indígenas (Gruzinski 1993; Hidalgo y Castro 1999). Construcción y reducción a pueblos de la dispersa población indígena, construcción de escuelas y eliminación del idioma nativo, canalización y fertilización de los campos, permitían el fomento de la población y le "franqueaban más proporciones para civilisarlos" (AGI, Charcas 425, foja $2 r$ ). En esa misma campaña se vieron afectados aquellos modos de expresión como las "con- 
versaciones indecentes", los juramentos "con ofensa de Dios", las borracheras y todos los vicios e imperfecciones a los que los indígenas estaban acostumbrados desde tierna edad (AGI, Charcas, 425 , foja $5 v-6 r)$.

Groserías, juramentos y obscenidades, ha señalado Bajtin en su clásico estudio de la cultura popular en la obra de Rabelais, aparecen como los elementos extraoficiales del lenguaje y eran considerados como una flagrante violación de las reglas normales del lenguaje, expresando un rechazo deliberado a adaptarse a las convenciones verbales (etiqueta, cortesía, piedad, consideración, respeto del rango); transformándose en un lenguaje particular, en un modo de expresión específico, que conduce a la formación de un grupo especial de personas: la muchedumbre de la plaza pública, en sus días de fiestas, ferias y carnavales (Bajtin 1999: 168-169). Precisamente, ese grupo diferenciado, para nuestro caso el de los indígenas en sus días de fiestas y convites colectivos, al hacer uso de un lenguaje extraoficial (e incluso al hablar una lengua distinta al castellano), se sustraía al control político e impedía la homogenización esperada por el paradigma de la civilización. Sustracción al control que se hacía más evidente en las borracheras que acompañaban a los días de fiestas.

Las fiestas y convites, con su consumo de licores y brebajes, abrían el espacio del vicio y de las imperfecciones alentadas por la embriaguez. Desprovistos de entendimiento y de luces para discernir, dominados por su innata desidia, vicios y perversidades, según los juicios de los corregidores Paniagua y Argumaniz, el único objeto al que eran propensos los indios era a la embriaguez (AGNA, Criminales, legajo $10, \mathrm{~N}^{\mathrm{o}} 3$, foja $3 \mathrm{v}$. AGNA, Criminales, legajo 6, expediente 8, foja 6r). Esas carencias y cualidades innatas parecían extremarse bajo el influjo del alcohol, olvidando los respetos debidos a la majestad real en las personas de sus corregidores.

Tal fue lo acontecido al corregidor Paniagua, hacia 1777, cuando una muchedumbre de indios ingresó con gran algarada a las casas cabildantes del pueblo de Ingaguasi, junto al cura y a los oficiales reales que venían, estos últimos, a desproveerlo del cargo de corregidor (Figuras 1 y 2 ). Los indios ingresaron "enteramente ebrios sentandose junto a su merced en tono de mofas y burla", agregando otro testigo de estos sucesos, que "caiendose de ebrios empesaron a hacerle burla faltandole al decoro queriendo tomar las manos unas veces y otras empujandolo poniendoselas en el hombro" (AGNA, legajo 10, $\mathrm{N}^{\mathrm{o}} 3$, foja 3v, 11v).

Obviamente, que estas observaciones tendían a reafirmar los juicios de los corregidores sobre los vicios y perversiones de los naturales y su propensión a la embriaguez; reflejando, además, la rusticidad, la miseria y la barbarie en que se encontraban los habitantes de la provincia de Atacama. Formaban parte, además, de los estereotipos coloniales que habían fijado una representación del indígena y que permitían la reproducción de las condiciones que legitimaban el dominio y las subordinaciones. Pero el gesto de los indígenas, ebrios y burlescos, debe entenderse en un contexto diferente, alejado de la asepsia y seriedad del poder, para ser introducido en un complejo entramado, del cual sólo tenemos fragmentos, y que permite recomponer una cierta concepción que los grupos subalternos elaboraron en oposición, no siempre abierta, frente a los discursos y prácticas de control y homogenización alentados por la élite.

Hay una tendencia, entre los antropólogos y etnohistoriadores, a pensar las prácticas culturales de las poblaciones indígenas coloniales como si estas pertenecieran a universos culturalmente cerrados, y como si la cultura fuese una realidad supraorgánica. Ningún lugar hay ahí para las elaboraciones de individuos o grupos. Se supone que esos "universos culturalmente cerrados" entran en contactos descuidando, precisamente, que las relaciones culturales se dan entre individuos y grupos. Ahora bien, una forma cultural lo es en relación a una práctica cultural que sirve de soporte y de reproducción a estrategias socialmente diferenciadas. En ese sentido, habría que explorar los lazos, las mixturas, las apropiaciones de lenguajes, que se dan entre los propios grupos subalternos, a pesar de la insistencia de los grupos dominantes por mantener el orden y la naturaleza innata a cada casta. Y no resulta aventurado sostener que las poblaciones indígenas se apropiaron de los lenguajes de inversión, atribuidos a las fiestas y carnavales, en una lógica distinta a las de las redefiniciones étnicas. Porque dicho lenguaje representaba una cierta oposición a las lógicas de 


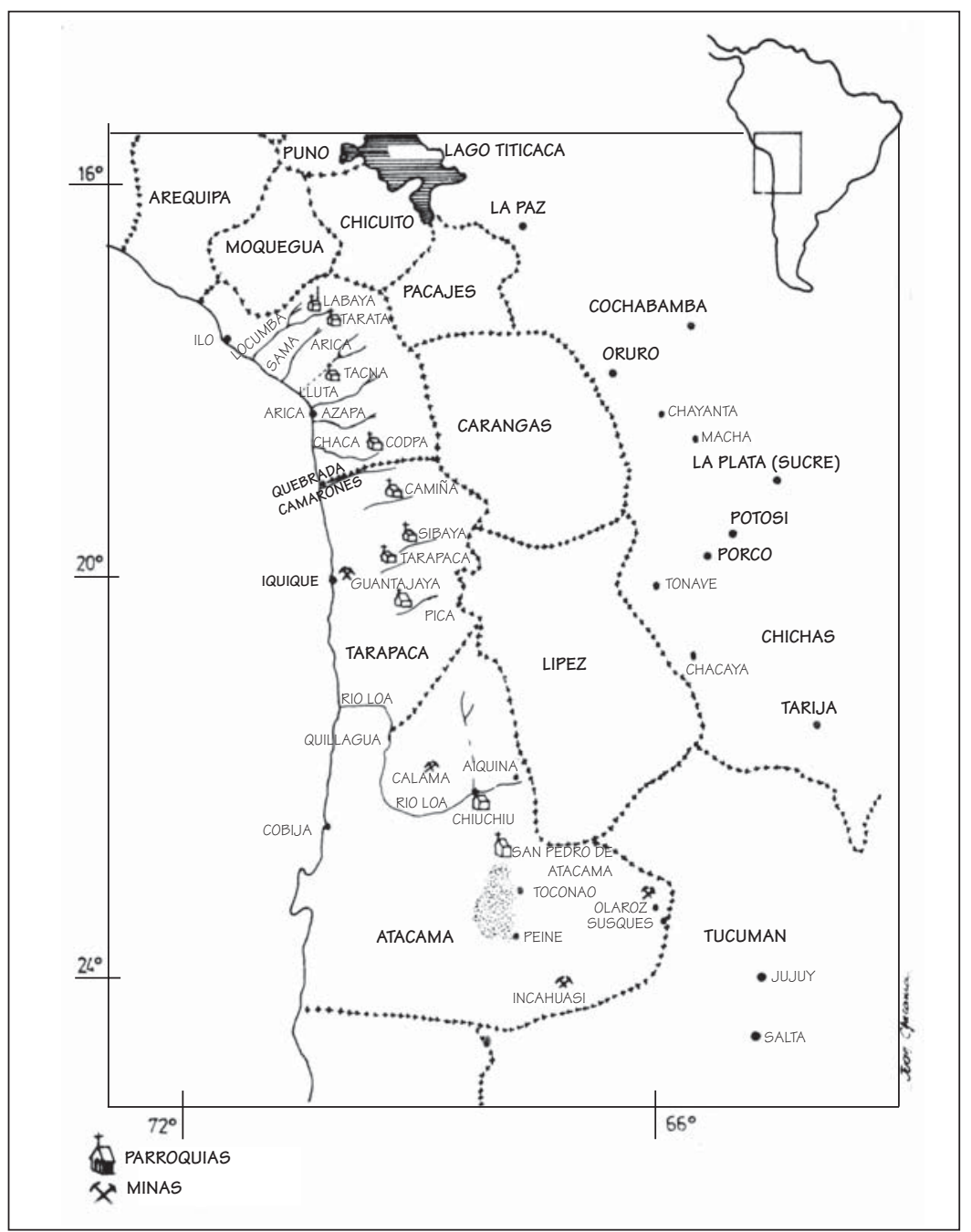

Figura 1. Mapa de los Corregimientos de Arica, Tarapacá y Atacama (Fuente: Hidalgo 1982).

dominio, con su tendencia ambigua a la diferenciación estamentaria (república de indios, castas) y a la homogenización propia al universalismo (ya sea bajo el paradigma de la cristianización o del paradigma de la civilización), y a los discursos que el propio liderazgo indígena elaboró para diferenciarse del común de indios.

Hemos planteado que las fiestas, al involucrar a todo el pueblo, permitían generar un sentido de pertenencia que rompía con los límites estamentarios. Ese sentido de pertenencia no puede entenderse sino es en el cruce de modos de expresión y de prácticas culturales que siguen la lógica del mestizaje cultural que se había ido produciendo en las porosas fronteras interculturales. Consideremos nuevamente a los indios ebrios y burlescos. Las borracheras no pueden ser entendidas desde la estrecha noción del vicio y de las perversiones connaturales a los indígenas, ni pensadas como "válvulas de escapes" frente a situaciones de deprivación colonial. En un lúcido análisis, Saignes (1993) se ha enfrentado a dichas nociones estableciendo que uno de los impactos que tuvo, por nombrarla de algún modo, la redefinición de las prácticas culturales andinas prehispánicas fue que los curaca perdieron el predominio que tenían sobre el consumo ritual de chicha. La práctica del beber, con la introducción de licores y brebajes, se extendió a toda la población permitiendo entonces a cualquiera una experiencia que estaba ritualmente reservada a las élites prehispánicas. Abriéndose a una experiencia muy distante de los vicios y perversida- 




Figura 2. Detalle del Corregimiento de Atacama (Fuente: Hidalgo 1982).

des: una experiencia de lo sagrado y la apertura hacia una memoria en la que era posible recorrer un otro tiempo. De un modo similar, Abercrombie (1993) ha señalado la relación entre el beber y el recordar entre los k'ulta de Bolivia y el modo en que se apropian de un cosmos colonizado. Precisamente, esa memoria autónoma, abierta por las borracheras, sigue permitiendo una experiencia de la historicidad, para dar un nombre a la forma en que los hombres experimentan los acontecimientos, un modo de incorporar la huella de los acontecimientos. No debería extrañarnos entonces que los indios ebrios proclamaran gritando que "echarian a todos los españoles de este asiento sin quedar uno quedandose solos en sus tierras como que son suyas y no del Rey de España" (AGNA, Criminales, legajo $10, n^{\circ} 3$, foja $5 \mathrm{v}$ ).

Proclamaban esto, estando "borrachos y mui insolentados profiriendo palabras mui denigrativas [a] dicho señor corregidor" (AGNA, legajo 10, $\mathrm{N}^{\mathrm{o}}$ 3, foja 6r), y haciéndolo con tonos de mofas y burlas. Con cuanta insistencia el corregidor Argumaniz había prohibido que los indios se diesen en hablar "conversaciones indecentes". Ese lenguaje extraoficial aparecía con su carga de desprecio de toda norma, del respeto debido a la dignidad y al cargo del corregidor, entre otras cosas. Los tonos de mofas y burlas, tan propias de los días de carnaval, revelaban una curiosa apropiación, por parte de los indígenas, de un componente de la concepción cómica del carnaval. De ahí que propongamos leer en clave festiva algunos fenómenos de resistencia al mal gobierno. El tumulto de Ingaguasi adquirió potencia en los días del carnaval de febrero de 1775 , dejando, al pueblo y mineral del mismo nombre, totalmente despoblado y a la máxima autoridad de la provincia teniendo que huir buscando auxilio en la provincia de Tucumán. Las conductas y el lenguaje propio de los días festivos se extendieron por bastante tiempo y cobraron una nueva víctima en la persona del corregidor Paniagua. El escarnio sufrido por el propio corregidor siguió el ritmo de los días de carnaval; si no es el destronamiento del rey, en la medida que él representaba la majestad real, por lo menos lo es el del mal gobierno.

En la comicidad del carnaval y de la fiesta se expresaba esa concepción cómica del universo propia de la cultura popular europea y que, muy probablemente, ingresó junto con las disposiciones y 
restricciones del control político. Aun cuando Ingaguasi albergaba, al momento de los sucesos descritos en los Autos, una pequeña población de 150 indios, hay también un pequeño pero no despreciable número de población flotante y residente compuesta por españoles, criollos, mestizos y mulatos. A pesar de las distancias y reticencias que muchos atacamas tienen con los así llamados viracochas españoles, aumentadas por las diferencias lingüísticas y estamentarias, entraban en relación ora en la explotación minera, ora en los intercambios comerciales, compartiendo, además, aunque acentuado de modo contradictorio, un mismo marco de referencias proporcionados por las representaciones ideológicas de los grupos hegemónicos. Pero, en aquellos intercambios, también se dejaba entrever la circulación de algunos contenidos compartidos por los grupos subalternos ( $\sin$ que por ello pensemos que se trata de una unidad discreta), como es el caso indicado de la concepción cómica del universo que se oponía espontáneamente al racionalismo teológico, al universalismo y a la seriedad de los grupos hegemónicos.

Tal tendencia al racionalismo y al universo está claramente demostrada en el discurso del corregidor Paniagua para persuadir a los indígenas que depusieran el estado de alzamiento en el que se encontraban desde los sucesos de Ingaguasi. El corregidor les advirtió de la obligación que tenían de:

"ser fieles, agradecidos, obedientes y humildes vasallos del Rey de España nuestro soberano, y señor natural, que a costa de la sangre derramada de sus españoles, ha extendido los estandartes de la fe hasta estos bastos dominios que la divina omnipotencia le ha consedido a fin de que tenga la gloria de encaminar a estos neofitos a su Patria Celestial, sacandolo de las tinieblas, del abismo en que como gentiles vivian antes, y que lograsen los pribeligios de españoles, y no ignorasen las claras luces del Evangelio" (AGNA, Legajo 6, Expediente 8, foja 23r).

Con su tendencia al universalismo, este discurso se posicionaba frente a cualquier intento de diferenciación, que no fueran los estamentarios, y connotaba a cualquier intento por buscar una historicidad distinta a la del relato de la Salvación. De realizarse, esto sólo podría representar un regreso al tiempo de las tinieblas y del abismo en el que la gentilidad había hecho vivir a los indios. El indio gentil, convertido por la policía cristiana y política, debía referir su existencia toda a esa lineal temporal constituida por la Salvación y la Redención. En esa perspectiva, la vida, en "este valle de micerias, y trabajos, donde nos hallamos desterrados", era el paso obligado para merecer "la felicidad incomparable de la vida eterna". Aun cuando los indígenas compartían esos significados, demandando en algunas ocasiones la presencia de sacerdotes que aliviaran el sufrimiento de no morir sin bautizo ni confesión, y que les entregasen el "pasto espiritual", no siempre les era suficiente que las miserias y trabajos fueran el camino necesario para la "gloria eterna". Muchas de ellas podían resolverse en esta vida. De ahí que recurrieran a otros significados como los proporcionados por los curanderos y su riesgosa manipulación de lo sobrenatural cristiano (Castro e Hidalgo 1999).

Pero también las fiestas y borracheras les brindaban una forma espontánea de enfrentarse a las miserias y trabajos, no teniendo que esperar la muerte. Las fiestas, especialmente el carnaval, les ofrecía esa renovación de las cosas que los discursos oficiales, con su abstracción y universalismo, siempre posponían. Las burlas, las mofas, las risas y los juegos de los días de fiestas, y todos los excesos imaginables que podían surgir por el consumo de quilapana, chicha o de algún otro brebaje, contenían un elemento de victoria "no sólo frente al miedo que inspiran los horrores del más allá, las cosas sagradas y la muerte, sino también sobre el miedo que infunden el poder, los monarcas terrenales, la aristocracia y las fuerzas opresoras y limitadoras" (Bajtin 1999: 87). Todo aquello que ofrecía el utopismo abstracto de la "Patria Celestial", con su retórica de la resignación frente a las miserias y trabajos y su no menos intimidante pastoral del miedo, y el universalismo del relato de la salvación-redención, con su obsesión por la linealidad de la historia, era tensionado, sino derechamente cuestionado, en el tiempo festivo.

Las fiestas, al involucrar a "todo el pueblo", configuraban un sentido de pertenencia colectiva que tomaba un camino distinto del tipo de comunidad político-religiosa impuesta por el control político colonial; situación que se veía enriquecida por la experiencia de las borracheras que abrían el camino a una memoria, aunque colonizada, que no se contentaba con la linealidad y el esquematismo 
del relato de la Salvación. De ahí que supervigilar las fiestas y convites, restringiendo el número de participantes y prohibiendo las borracheras, no respondiera tan sólo a un celoso cuidado del despilfarro de energías, sino que, sobre todo, a un empeño sistemático por recuperar el control del imaginario andino neutralizando cualquier expresión de autonomía.

\section{El documento}

El documento que aquí publicamos se encuentra rotulado como "Testimonio del expediente en que se comiciono a Don Joseph Maria Paniagua para la averiguación y pacificación del tumulto acaecido en la provincia de Atacama en el asiento de Yngaguasi por el año de 1775", y se encuentra depositado en el Archivo General de la Nación Argentina, Interior, legajo 6, expediente 8. De él existe una copia en el Archivo General de Indias. El expediente contiene los traslados de las averiguaciones hechas por Francisco de Argumaniz, corregidor de la provincia en el momento del "tumulto", quien fue sucedido por el corregidor José María Paniagua. Fue este corregidor quien, hacia
1777, interrogó a los testigos españoles que vivieron los acontecimientos de 1775 . También intentó "pacificar" el mineral de Ingaguasi, que había quedado, aparentemente, desierto tras el tumulto, pero sus esfuerzos se vieron frustrados por la llegada de los oficiales reales de Potosí. Estos hechos están descritos en un segundo documento, que por razones de espacio no publicamos, y que se encuentra titulado como "Testimonio de los Autos Criminales de oficio de la Real Justicia en la Provincia de Atacama por el teniente de Capitan General Corregidor de ella Don Josef Maria de Paniagua contra los Oficiales Reales de la Villa de Potosí sobre la Prisión del Corregidor" (AGNA, Fondo Criminales, legajo 10, número 3).

La investigación de archivo fue realizada por Jorge Hidalgo, como parte del Proyecto FONDECYT 1980638, y las piezas documentales sirvieron de soporte a un artículo publicado en esta revista (Hidalgo y Castro 1999). Hicimos una primera transcripción de dichas piezas documentales, que hemos mejorado en el actual proyecto, agregando, además, este estudio introductorio y los índices onomásticos y toponímicos.

\section{REFERENCIAS CITADAS}

ABERCROMBIE, T., 1993. Caminos de la memoria en un cosmos colonizado. Poética de la bebida y la conciencia histórica en K'ulta. En Borrachera y memoria. La experiencia de lo sagrado en los Andes, T. Saignes (Comp.), pp. 139-170. HISBOL-IFEA, La Paz.

BAJTIN, M., 1999. La cultura popular en la Edad Media y el Renacimiento. El contexto de Rabelais. Alianza Editorial, Madrid.

CASTRO, N. y J. HIDALGO, 1999. Brujos y brujería colonial en Atacama. Inorganicidad de una representación ideológica y diseminación de una matriz cultural. (Introducción y transcripción del "Cuaderno sobre varios delitos y supersticiones" del corregidor Manuel Fernández Valdivieso). En Estudios Atacameños 17: 91-124.

DAVIS, N. Z., 1993. Sociedad y cultura en la Francia Moderna. Crítica, Barcelona.

DELUMEAU, J., 2002. El miedo en Occidente (siglos XIV y XVIII). Una ciudad sitiada. Taurus, Madrid.

FONTANA, J., 2002. Europa ante el espejo. Crítica, Barcelona.
GONZALEZ CASANOVA, P., 1948. Misoneísmo y modernidad cristiana. El Colegio de México, México D. F.

GONZALEZ, S., 2002. Condena y tolerancia de la embriaguez en Arica, Tarapacá y Atacama en la segunda mitad del siglo XVIII. Tesis para Optar al Grado Académico de Licenciado en Historia, Instituto de Historia y Ciencias Sociales, Facultad de Humanidades, Universidad de Valparaíso, Valparaíso.

GINSBURG, C., 1997. El queso y los gusanos. El cosmos según un molinero del siglo XVI. Muchnik Editores, Barcelona.

GRUZINSKI, S., 1993. La colonización de lo imaginario. Sociedades indígenas y occidentalización en el México español. Siglos XVI-XVIII. Fondo de Cultura Económica, México D. F.

HIDALGO, J., 1982. Fases de la rebelión indígena de 1781 en el corregimiento de Atacama y esquema de la inestabilidad política que la precede, 1749-1781. Anexo: Dos documentos inéditos contemporáneos. Chungara 9: 192-246.

HIDALGO, J. y N. CASTRO, 1998. Fiscalidad, punición y brujerías. San Pedro de Atacama, 1749-1755. Estudios Atacameños 13: 135-160. 
- 1999. Rebelión y carnaval. Ingaguasi (San Pedro de Atacama), 1775-1777. Estudios Atacameños 17: 61-90.

MANDROU, R., 1962. Introducción a la Francia moderna. UTEHA, México D. F.

MEMORIAS, 1856. Memorias de los Virreyes del Perú. Tomo IV, Librería Central de Felipe Bailly, Lima.

-1859. Memorias de los Virreyes del Perú. Tomo VI, Librería Central de Felipe Bailly, Lima.

SAIGNES, T., 1993. Borracheras andinas: ¿Por qué los indios ebrios hablan en español. En Borrachera y memoria. La experiencia de lo sagrado en los Andes, T. Saignes (Comp.), pp. 43-71. HISBOL / IFEA, Lima.

VOVELLE, M., 1985. El desvío por la historia en el redescubrimiento de la fiesta. En Ideología y mentalidades, pp. 187-198. Ariel, Barcelona.

\section{Documentos}

"Sobre borracheras de Indios", Archivo General de Indias, Charcas 498, 1774.

"Expediente que acredita los meritos de don Franzisco de Argumaniz corregidor que ha sido de la provincia de Atacama”, Archivo General de Indias, Charcas 425.

"Testimonio de los Autos Criminales de oficio de la Real Justicia en la Provincia de Atacama por el teniente de Capitan General Corregidor de ella Don Josef Maria de Paniagua contra los Oficiales Reales de la Villa de Potosí sobre la Prisión del Corregidor", Archivo General de la Nación Argentina, Fondo Criminales, legajo 10, $\mathrm{N}^{\circ} 3$. 


\section{Archivo General de la Nación Argentina Legajo 6 \\ Expediente 8 \\ 1775}

Testimonio de expediente en que se comiciono a Don Joseph maria de Paniagua para la averiguación y pacificación del tumulto acaecido en la Provincia de Atacama en el asiento de Ingaguasi por el año de 1775. [Rubrica] Escribano de camara Don Sebastián Antonio Toro.

Foja 1r

Don Carlos, por la Gracia de Dios, Rey de Castilla, de Leon, de Aragon de las Sisilias de Jerusalem, de Navarra, de Granada de Toledo, de Valencia, de Galicia de Mallorca, de Sevilla, de Serdeña, de Corseja, de mursia de Jaen de los Algarbes, de Algesira, de Gibraltar de las Islas de Canaria, de las Yndias, Orientales y Occidentales, Islas y Tierra firme, del mar oceano, archiduque de Austria, Duque de Borgoña de Brabante y Milan, Conde de Aupurg de Flandes de Tirol, y Barcelona, Señor de Viscaya y de Molina etcetra. A voz Don Nicolas Leon de Oxeda, y por vuestro defecto o lejitimo impedimento a Don Philiberto de Mena, personas nombradas por el nuestro Precidente, aquienes cometemos la execucion y cumplimiento de lo que adelante se hara mension, en esta nuestra carta, y Provicion Real, Salud, y gracia sabed que ante el nuestro Precidente y Oidores, de la nuestra Audiencia y chancilleria Real, que recide en la ciudad de la Plata Provincia de los Charcas del Perú, se presentó el Ynforme instruido del testimonio que en el se refiere, cuio tenor sacado a la lettra

Foja 1v

con lo que dijo, y respondio, el nuestro oydor que ejersia de fiscal a la vista que se le dio, auto en su razon probeido y el que en el se cita es como se sigue. Vistos con lo expuesto por el señor oydor que hase de fiscal le viere Real Provicion, para que don Josef Canisares inmediatamente, y sin repli$\mathrm{ca}$, ni escusa alguna pase a la aberiguacion de todos los hechos que se contienen, la representacion que ha dirigido a esta Real Audiensia, el Casique y Alcalde maior del Pueblo de San Pedro de de Atacama la alta, Don Agustin Ramos, recibiendo para el efecto la respectiba Sumaria Ynformacion, y prendera a todos los que resultaren culpados, y principales autores del movimiento y sublebacion que se relaciona, y embargandoles sus vienes, los remitira presos a su costa a esta Real Carcel de Corte con buena guardia y custodia, y las diligendias que obrare, serradas y selladas, las dirijirá con la seguridad correspondiente, y parasu mas pronta actuacion, notificará al Corregidor de la Provinsia Don Francisco Argumanis, que con ningun motibo ni pretexto, se entrometa en esta cauza, ni impida ni embarase directa bu ibdirectamente al Comicionado, las diligensias que debe practicar con apercebimiento, que por la mas lebe contrabension, en negocio tan importante, se le hara compareser en esta Real Audiencia; y se le ympondran las penas que hubiese lugar en derecho. dos rubricas Probeiron y rubricaron el auto de suso los señores

Foja 2r

Precidente y Oidores de esta Real Audiensia, y fueron Jueses los Señores Doctores Don Pedro de Tagle, Caballero del orden de Calatraba, y Don Josef Lopes Lisperguer, oydores en la Plata en primero de Junio de mil

Ynforme setecientos setenta y cinco años- Don Sebastian Antonio Toro- Muy Poderozo Señor- El teniente de Ynfanteria Don Francisco de Argumanis Fernandez, actual Corregidor, y justicia mayor de la Provincia de Atacama, ausente de ella, en este valle de Calcachi Jurisdiccion de la del Tucuman con el mas profundo respeto, haze presente a Vuestra Alteza, que con fecha de dies y nuebe de noviembre del año proximo pasado remitio a ese Regio Tribunal, la cauza original, que formó de oficio, sobre el robo que cometio Valeriano Purulla Yndio originario, y Casique Cobrador de los reales tributos en dicha Provinsia de Atacama, de Cinquenta onzas de oro, respectibas a dicho ramo, en cuia ocacion el Corregidor, representó a Vuestra Alteza por informe que hizo, y ultimo auto que probeio en dicha cauza eran comprehendidos en el citado robo los Yndios principales de dicha Provincia sujeridos de otras Perzonas que debieran en cumplimiento de sus empleos propender, a la paz, y quietud de las republicas en aquella jurisdiccion, y que por esta razon se hallaban sus naturales, aliados, y amotinados

Foja 2v

con el artificioso disfras contra la Real Justicia que en nombre de Su Magestad (Dios le Guarde) ejerse el Corregidor, sin poderla administrar con la amplitud que se requiere, por careser de todo auxilio, lo que igualmente 
Ynformo en la misma ocacion al Superior Govierno de estos Reynos, y repitio por otra representacion que hizo a su exselensia, con el motibo de que no pudo verificar la revicita general que le mando practicar, los insolentados osados, intrepidos, probocatibos; y nada obedientes que son los Yndios de dicha Provinsia de Atacama, por cuia razon, y la de no querer de sujetar, a vivir en Poblacion estaban poco menos que alsados, sin reconoser subordinacion a la justicia, ni vesindad, y aun en duda de la religion christiana, cuios hechos representados a ambos Superiores tribunales se hallana oy berificados por lo que expreza el caso siguiente. Haviendo salido el dicho Corregidor, en cumplimiento de su ministerio del Pueblo de Atacama el dia trese de marzo de este presente año a practicar la vicita annual de minas en el serro de Yngaguasi terminos de dicha Jurisdiccion distante cien legus del referido Pueblo, experimento en el discurso de once dias de viaje por los Yndios sus subditos y tributarios de ella muchos vejamenes, desafios amenazas, hostilidades, e improperios, sin respecto a la representacion de su empleo

Foja 3r

ni atension a la justicia, que en nombre de $\mathrm{Su}$ magestad administra, y a su arribo a dicho mineral lo hallo enteramente decierto, y despoblado, sin haver tenido a quien preguntar la cauza de ello porque los Yndios havian hechado a pedradas a todos los mineros, y Españoles que contenia, y se remontaron, aquellos a los Cerros circumbecinos, y haviendo practicado el Corregidor todas las diligensias posibles baliendose de los medios mas suabes para atraerlos, no solo no quisieron compareser en su presensia, sino que desobedeciendole enteramente, le negaron aun los auxilios para poderse regresar a su casa, de Atacama propasandose su osadia a los terminos de yntimarle que saliese de aquel haciento sin detension con repetidas amenazas dignas del mas sebero castigo, y conciderandose el Corregidor solo, destituido, de todo amparo imposibilitado a bolberse a dicho Pueblo, se vio presisado a trasladarse de aquella Prouinsia a esta del Tucuman como mas inmediata, y confinante a aquella, lo que verifico con un harriero que la suerte le deparo, con quien a todo riesgo abandonando su hacienda, y equipaje salio de dichas minas con el cilensio de la noche para no ser sentido, receloso de que los Yndios llegasen, a cometer el ultimo absurdo de quitarle la vida foja $3 \mathrm{v}$

y arribo el dia primero de Abril, proximo pasado, a este dicho Valle de Calchaqui, jurisdiccion de la ciudad de Salta - Llegado que fue el Corregidor al mencionado Valle, sin perdida de tiempo por pronto remedio, pidio a la Capitania General del Tucuman los correspondientes auxilios, asi para la aberiguacion de los Sublebados, que uno, y otro se le franquearon, nombrando para lo primero a Don Sebero de Yrasmendi, y para lo segundo a Don Josef de Canisares; pero hauiendo transendido estas prouindensias a los Yndios de Atacama, que viben dispersos en dicho Valle, dieron quenta de ellas a los que residen en el exprezado mineral de Yngaguasi, y que estos los comunicaronb a los que viven en el interior de dicha Prouinsia, y teniendo noticia el Corregidor, que asi estos como aquellos hauian resuelto desamparar aquella jurisdiccion, y aucentarse a otras como lo ejecutaron el crecido numero de Yndios que ocupaban dicho mnineral, deseando el Corregidor la pasificacion de su Prouinsia, y que no quedase de una vez decierta y despoblada tube por combeniente el suspender, diferir la entrada en ella con los cinquenta hombres armados que se franquearon por el Gouernador del Tucuman, y porceder a la Sumaria informacion del susseso que la practico dicho comicionado

foja $4 \mathrm{r}$

cuio original remite el Corregidor al Superior Gouierno de estos Reynos, y a Vuestra Alteza en esta ocacion, el testimonio en foxas ciento beinte y una utiles - Ympuesto vuestro Real Solio de dicha sumaria, reconosera que una de las razones principales que conccurren para que dichos Yndios de Atacama se hallen tan sobre si; y que cometan tan repetidos desacatos y desobediencia, que ha experimentado el Corregdior, dimana de estar apadrinados acosejados, y sobstenidos de su Cura de dicho Pueblo, Doctor Don Manuel Geronimo de Olmedo (como los mismos Yndios lo vosiferan) cuio genio dominante, quimerico, belicoso, lo ha manifestado con todos los Corregidores esmerandose con el actual con el maior escandalo; y si aquellos no expucieron a Vuestra Alteza sus justas quejas de los vejamenes, groserias, libertades, que les infirio y las escandalozas operaciones de dicho Cura respecto de ministerior, fue porque les falto el tiempo saliendo de dicha Prouinsia bien escarmentados, sin mas recompenza que la de hauer experimentado, 
otros muchos oprobios del mesionado Cura, cuias probocaciones impropias de su estado, y ajamiento de los ministros del Rey, no tienen otro objeto que el manifestar al Publico la Superioridad, y despotismo que se figura en si para que especialmente la crianza, ignoransia de los Yndios

Foja 4v

lo respeten como a cabeza principal, y unica de la Provinsia, no solo en lo espiritual, sino en lo temporal, para lograr de este modo el que la Real Jurisdiccion, se mire con total desprecio, y por consiguiente, el quedarse solo en ella para poder mandar con libertad a los Yndios, que trabajen las minas, y que contribuian con el oro para saciar, en algun modo su sobrada codicia: a cuio fin no ha dejado de promober en el dicho mineral para extrañar de el a los españoles que contenia sin eseptuar, a los dueños de minas, como asi mismo, para que estos, siendo expulsados no pudiesen ser testigos de sus operaciones ni menos probar el Corregidor los Capitulos que le tiene puestos ante Vuestra Alteza, y protextada su justificacion, asi con las personas originarias de dicha Prouinsia como con los citados españoles, contra quienes, y el Corregidor es el Sistema, el encono de dicho Cura - Para calificar de ciereta la relacion que ba exprezada, y codisia que le asiste a dicho Cura, es buen comprobante el documento que en testimonio acompaña, a esta representacion, con el que se quedo el Corregidor, hauiendo dado quenta con el original el dia de su fecha, a los oficiales Reales de Potosi, persuadido a que aquel tribunal debia entender en el asunto que expreza dicho Documento - Y para patentificar que el mensionado Cura

Foja 5r

de Atacama, propende por todos medios a entender en los asuntos gobernatibos, que no son de su inspeccion, y la enemiga declarada, y mala voluntad que le profesa al Corregidor, acredita la carta respuesta original, que igualmente acompaña a este Ynforme, escrita, y firmada de puño, y letra del mensionado Cura a Don Josef Barela, en ocacion que este se hallaba en el de Chiu Chiu, entendiendo en la aberiguacion de los falsos Capitulos, que contra el honor del Corregidor, expuso a Vuestra Alteza, el Casique principal de aquel Pueblo Don Josef Ramos Mundaca (uno de los comprehendidos en el robo de dichas cinquenta onzas de oro de Reales tributos) practicando de este modo el referido Cura, oficios impropios, de su estado, y caracter, sembrando sisaña con dicho juez, para que este acriminase mas la cauza al Corregidor, cuio contexto comprueba, ser dicho Cura quien ha fulminado, los pleitos contra el Corregidor, y que desea su prosecucion con el parapeto y sombra de dichos Yndios. tambien corrobora la asercion, de que dicho Cura es directamente, opuesto a todos los españoles, la Carta que le escribio desde Atacama a dichas minas del Yndio Alejo Ventura dandole ordenb de que no quedase en aquel haciento español alguno, para quando el Corregidor llegase; como mas pormenor consta de dicha Sumaria - El motibo

Foja 5v

principal que tubieron dichos Yndios, para no hauerle prestado, a su Corregidor la debida abediensia, quando llego a las minas, y se hubiesen alsado, contra el, negandonsela como tanbien todos los demas auxilios, y cometido los desacatos que aparesen de dicha Sumaria fue por hauer escrito dicho Cura, la Carta que ba exprezada, al referido Yndio de que resulta que la cauza de dicho alsamiento de los Yndios contra la justicia es el exprezado Cura de Atacama como asimismo para que aquellos le haian puesto al Corregidor ante Vuestra Alteza los iniquos injustificables Capitulos y pleitos, que estan pendientes no siendo estos, mas que imposturas suscitadas por el mensionado Cura, para macular el honor, y conducta del Corregidor y para captar las boluntades de dichos Yndios y sujerirlos a que prosigan, en ellos, les a aparentado, que se libertaran de pagar el reparto que les ha hecho a cuio fin, les ha suplido dicho Cura, barias cantidades de dinero, para sobstener dichos pleitos, y no es dudable que para propagarlas les haia industriado, a que hechen repetidas derramas, con conosido perjuicio y atrazo de los dichos minerales, en contrabension de las reales ordenanzas, imposibilitando de esta forma el cobro de sus respectibas taras como todo consta por extenso de dicha Sumaria; y es digno

\section{Foja 6r}

notarse que un sujeto graduado, y caracterisado como lo es dicho Cura, tenga la osadia de fiar lo que siente en parte su corazon, en cartas que con presision han de pasar por muchos ojos, antes de que queden inteligensiados los rusticos de sus corresponsales los Yndios, quienes por no saber leer es indispensable se balgan de de otros, para que sean buenos testigos, y fiscales de sus secretos, cuio arrojo es claro, nace no de insufi- 
ciensia en dicho Cura, sino de querrer figurar, que no llegan a ser pecados beniales lo que fia a unas cartas voladas respecto del veneno que entierra en su pecho contra el Corregidor - Tampoco duda el Corregidor de que tenga dicho Cura la maior parte de culpa, en que los Yndios le haian salteado y robado diferentes pliegos del real seruicio que remitio a Vuestra Alteza, Superior Gouierno, y oficiales Reales de Potosi, cuio indicio veemente tubo el corregidor por hauerle manifestado dicho Cura, en presensia de Don Pedro Pavlo Gonzalez escribano receptor del numero de esta Real Audiensia, disiendole que si supiera el jiro qu hauian llebado sus proyectos no hubiera citado tan alegre el dia de su Santo; lo que le puso en cuidado al Corregidor, quien comenzo a indagar la cauza y a brebe rato supo radicalmente, que los Yndios de Atacama, ahuian atajado en el camino a Potosi a un propio llamado Gregorio Araya, que mando con dichos pliegos, a quien se los quitaron imponiendole grabes penas, y amenasandole si se presentaba

\section{Foja 6y}

ante dicho Corregidor, para que no tubiere motibo de declarar los complises de dicho salteamiento por cuia razon tubo dicho propio a bien de ausentarse a la Prouinsia del Tucuman, cuia relacion del Cura puede certificar el mensionado Escribano receptor sobre cuio hecho formo cauza el Corregidor la que esta pendiente por la ausensia que hizo el exprezado proprio - No tiene el corregidor mas delito, para ser desobedecido, capitulado, y repudiado por sus Yndios que las razones que ban expresadas, y el de ser provisto por $\mathrm{Su}$ magestad por cinco años (termino en que es facil poder cobrar el repartimiento que justa y christianamente ha hecho) y como han estado acostumbrado a tenerlos, por los dos que el Superior Gouierno les asigna, de aqui nace que como en tan limitado tiempo, no han podido cobrar los antesesores del actual Corregidor sus respectibos repartos estan acostumbrados dichos Yndios a quedarse con ellos para remediar las necesidades a que su innnata desidia, vicios y perbercidad los conduce, y mas quando hallan apoyo para ello y para solicitas con falsas imposturas el desconceptuar al Corregidor y entretenerlo de esta forma, con continuados pleitos, y ber si por ellos se le suspende del empleo para berse libres del rexto de pagar lo que tan justamente le deben - De todo lo relacionado resulta que el Corregidor se halla aucente de su prouinsia, y sin
Foja7r

uzo, ni ejersicio en su ministerio, los Yndios viviendo a su libertad, los tributos de $\mathrm{Su}$ magestad sin cobrar, las ordenes del superior Gouierno, y de Vuestra Alteza sin su debido cumplimiento por cauza de dicha aucensia, el importe de las bulas sin recaudar, el papel sellado que se remitio de las Cajas de Potosi, sin recojer, la vicita General sin poder concluir; y por ultimo la familia de muger y seis hijos, y hacienda del Corregidor que dejo en su casa del peublo de Atacama expuestos a los riesgos que se dejan conciderar, y mas quando no ha podido internar una carta, ni otras prouidencias comestibles desde que salio de su dicha casa, por el motibo de que se quedan con ella los conductores Yndios de dicha Prouinsia; por cuia razon ignora el Corregidor si dicha su familia es muerta o viva Enterada la alta penetracion de Vuestra Alteza, del estado en que se halla dicha Prouinsia, su Corregidor, y lo que resulta de dicha Sumaria, debe haser precente que el medio mas suabe que halla para sosegar dichos Prouincianos de Atacama, sera el ceparar de la mensionada Probinsia y Curato al expresado Doctor Don Miguel Geronimo de Olmedo, prvidensiando Vuestra Alteza, en este particular lo que fuere de vuestro Real aggrado, para que en lo subsesibo le sirba de continensia, y a otros de exemplo mandando al mismo tiempo compareser ante ese regio tribunal

Foja 7v

a los Yndios que resultaron culpados en la cauza que el Corregidor siguio contra Valeriano Purulla Casique cobrador de tributos sobre el robo que cometio de la consavidas cinquenta onzas de oro pertenencientes a este ramos que se halla preso; como tambien a los que pareciere Vuestra Alteza son los principales causantes del citado alzamiento contra la justicia, en vista de la sumaria hecha por la del Tucuman - Ygualmente espera el Corregidor de la recta justicia de Vuestra Alteza se digne mandar compareser ante vuestro Real Solio a Don Agustinb Victorio Ramos, Casique principal del Pueblo de Atacama exsonerandole del cargo de dicho casicasgo, castigandole los exsesos que ha cometido de nombrar, y quitar los Alcaldes a su arvitrio sin hauer dado quenta a su Corregidor, y por hauerse propasado a echar derramas en contrabension de las reales ordenanzas, y que satisfaga y pague al Corregidor los tributos que tiene cobrados por los tercios bendidos de San Juan y Nauidad, de setecientos seten- 
ta y quatro que retiene en su poder, con fines particulares, y detrimento de la Real hacienda, del Corregidor, y sus fiadores - Y en atension a que los Yndios de dicha Prouinsia de Atacama, han vivido hasta el presente montaras, y licensiosamente sin hauer querido reducirse a Poblacion reconoser subordinacion, ni Superioridad como ba mensionado, y el Corregidor lo tiene anteriormente representado

\section{Foja 8r}

a ese Regio tribunal, y al Superior Gouierno de estos Reynos, como ni tampoco, comparecer a la revicita que tiene mandado practicar para saber el numero fixo de tributarios que comprehenden, sobre cuio asunto el Corregidor se halla con segunda orden para su continuacion, se ha de serbir Vuestra Alteza mandar por pronto y eficaz remedio, que para quietud, y pacificacion de dichos Yndios, sean estos reducidos a Poblado, y vida sosiable como los demas del Reyno, y que de ellos se contribuia annualmente con el numero que disponen dichas Reales ordenanzas a la mita de la Villa de Potosi de cuia forma asegurara $\mathrm{Su}$ magestad con menos dificultad, y mas exactamente los Reales tributos, y por consiguiente los dichos Yndios que handan dispersos se recojeran a los Pueblos de su origen, se cultibaran la tierra de estos que hasta ahora se mantienen yermas, se civilisaran en los docmas de Nuestra Santa fe Catholica, y se evitara que vivan muchos de ellos bagantes y poco menos que Gentiles. Y para la maior paz $\mathrm{y}$ tranquilidad de dicha prouincia en lo futuro espera el Corregidor que Vuestra Alteza expedira la mas arreglada prouidensia para que los demas Curas se abstengan como $\mathrm{Su}$ magestad lo mandando en mesclarse directa, ni indirectamente en asuntos gubernatibos que son peculiares al Corregidor Suplica a Vuestra Alteza

Foja 8v

que en vista de lo que lleba exprezado, y resulta de dicha Sumariase digne mandar expedir la providencia mas conducente a fin de sosegar dicho alzamiento, y pacificar los Yndios de dicha Prouinsia, hauiendo un ejemplar castigo con los principales autores deel cuios espiritus de lo contrario siempre han de quedar inquietos, y por consiguiente todos los demas de aquella jurisdiccion, y que siendo de Vuestro Real agrado se le ponga al Corregidor en quieta y pacifica posesion de su empleo en dicha Prouinsia, a la que no se ha determinado entrar, por las razones que lleba manifestadas en el cuerpo de informe por obiar maiores incombe-nientes lo que solo podra ejecutar con la Superior orden de Vuestra Alteza, la que espera para maior acierto a que propende celoso del seruicio de $\mathrm{Su}$ magestad o si fuere de vuestro Real agrado el que el Corregidor las reciba personalmente ante ese Regio tribunal dara a todas las que se dignase, resolber el pronto devido lleno cumplimiento - Dios Guarde la Catholica Real Perzona de Vuestra Alteza con aumento de maiores Reynos, y Señorios los años que la christiandad ha menester Valle del Calchaqui a treinta y uno de maio de mil setecientos setenta y cinco.

Respta Francisco de Argumanis Fernandes - Muy Poderos Señor $=$ El oydor que hase de fiscal en vista de la sumaria que con este Ynforme remite el Corregidor de la prouincia de Atacama obrada por Don Sebero de Yrasmendi comicionado

\section{Foja 9r}

para el efecto por el Gouernador del tucuman en virtud del exorto, que para ello le libro el mismo Corregidor de Atacama, sobre la Sublebacion, y movimientos que se experimentaron en el mineral de Yngaguase jurisdiccion de la citada Prouincia de Atacama, y con reconocimiento de los antecedentes que hauian en esta Real audiencia sobre el propio asunto, y prouidensia tomada en el por Vuestra Alteza. dice: que reconosiendose estar dicha Sumaria, recivido por Juez incompetente; pues no lo pudo ser ni el Gobernador del Tucuman, ni su Comicionado por no ser Superior de aquella prouincia estando al mismo tiempo tomadas las declaraciones, en territorio del Tucuman, y contra sujetos que no son de su jurisdiccion ni cometieron delito en ella, se ha hecho nula, y de ningun valor esta actuacion. En cuos terminos respecto de hauer Vuestra Alteza Comicionado a Don Josef Canisares por auto de primero de junio, para pasarse a la aberiguacion de todos los hechos susedidos en el referido mineral. Siente que siendo Vuestra Alteza servido podra mandar que a este mismo se le remita dicha sumaria a fin de que haciendola ratificar proseda en lo demas con arreglo a lo que se le tiene ordenado por Vuestra Alteza en el exprezado auto - Y por quanto dicho Corregidor de Atacama, denuncia al Cura

Foja 9v

Doctor Don Miguel Geronimo de Olmedo de hauer erejido en el citio que llaman los Chorrillos dos trapiches sin licencia Superior, siente 
este unasunto diberso del que contienen estos autos, y por lo mismo deberse tratar, y seguir en cuerda ceparada, se ha de servir Vuestra Alteza mandar que segregandose de estos autos el documento de foxas ciento beinte y tres, con el que instruye dicha denuncia el referido Corregidor, y agregandose a el, este pedimento, y prouidensia que se tomare se le pase, que en su vista protexta exponer y pedir quanto conceptue justo. Plata y julio dies y siete de

Auto mil setecientos setenta y cinco - Ruiera- Vistos librese Real Prouicion para que la perzona que nombrare el señor Precidente la qual sea de la Prouincia del Tucuman, dandosele por el Gobernador Don Geronimo Matorras, y demas justicias los auxilios que sean nesesarios: pase prontamente a la Prouincia de Atacama; y porsediendo con la devida refleccion, y madurez procurara por los medios que le dictare la prudencia tranquilisar los Yndios, para que cumplan sus obligaciones obedeciendo y respetando a su Corregidor Don Francisco Argumanis, a quien restituira, y repondra en su empleo quieta, y pacificamente, arreglandose en todo a la instruccion que se le dirigira por el señor Oydor que hace de fiscal lo quefecho y conseguida la tranquilidad de la Prouinsia procedera a la aberiguacion de los autores del tumulto, y prendera a los que

Foja 10r

resultaren grabemente culpados, remitiendolos a esta Real Audiencia, segun, y en la forma que se halla mandado en el auto de primero de junio del precedente año, cuio tenor cumplira recojiendo para ello de Don Josef Canisares, la Real prouicion que se libro, y las diligencias que hubiere actuado, las que ratificara como tambien la Sumaria que por Comicion del Gobernador del Tucuman remitiendosele el testimonio que della dirijio dicho Corregidor de Atacama. Y respecto de contar que el Cura Don Miguel Geronimo de Olmedo sin licencia de la Real jusiticia ni obserbar lo prebenido en las reales ordenanzas fabrico, y trabaja dos trapiches que nbo pudo ni debio fabricar, ni usar en atension a lo que a expuesto, y demas que se tiene presente, para no confiscarselos hara saber que presisamente en el termino de tres mezes, los bendera a perzona secular, con apercibimiento que pasado dicho termino se daran por decomisados prebiniendosele que en lo subsesibo se abstenga de mesclarse, en semejantes negosiaciones, muy ajenas y prohiuidas a su estado porque de lo contrario se expediran las mas eficases prouidencias. Y expresando dicho Cura no hauersele pagado el sinodo que le corresponde notificara al mensionado Corregidor que sin falta alguna en los plazos que se hallan asignados

Foja 10v

por el superior Gouierno, Prouiciones de retazas y reales ordenanzas le satisfaga puntualmente con apercivimiento que si no lo hisiere se despachara juez a su costa para que verifique la paga del sinodo. Yconcluidas las diligencias que prebienen, con ellas dara quenta el Comicionado con el Ynforme correspondiente - dos rubricas - Probeiron y rubricaron el auto de suso los Señores Precidente y Oidores de esta Real Audiencia, y fueron juexes los Señores Doctores Don Pedro de Tagle Caballero del orden de Calatraba y Don Josef Lopez Lisperguer Oidores en la Plata en dies y nuebe de Agosto de mil setecientos setenta y cinco años- Don Sebastian Antonio Toro = Y hauiendose hecho por el nuestro Precidente el nombramiento de juez, en virtud del auto suso incerto, se hizo saber a las partes, en cuio estado los Yndios, Alejo Ventura, y Diego Siaris presentaron escrito de recusacion, y en vista del y de la representación del nuestro fiscal Protector General se proveio auto, hauiendo por recusado a dichos juezes, y mandando se nombrase uno de los abogados de esta ciudad, el que igualmente se notifico, a las partes, y por la de Don Francisco Argumanis Fernandez, se representaron barios escritos y documenbtos en cuia vsita se probeio el auto cuio tenor sacado a la letra y de lo que expucieron el nuestro Oydor que

Respta ejercia de fiscal, y fiscal Protector General es como se sigue - Muy

Fiscal Poderozo Señor=

Foja 11r

El fiscal Protector General en vista de esta nueba representacion presentada por el Corregidor de la prouincia de Atacama, en la que presenta una carta del exelentisimo señor Virrey mandandole ejecute la revicita Dice: que con arreglo al auto de Vuestra Alteza de foxas podra permitirle pase a executar la orden de su exelensia y sus cobranzas graduando en todo, y por todo dicho auto con la prebencion de que haia de salir de todos los pueblos donde se hubiezen de examinar testigos, teniendo vuestra Alteza precente las respuestas anteriores que corren a foxas, para evitar a unas, y otras partes la malicia con que puedan proceder y los daños y perjuicios que se pueden causar no obstante que en la citada respuesta 
el fiscal Protector silicitase que el Corregidor permanesire en esta Corthe, por la cosntitucion de las cozas le hasen bariar de dictamen pareciendole arreglado el que ahora propone a la Vuestra Alteza, quien se serbira dar la prouidencia que se mas de su agrado. Plata y octubre nuebe de mil setecientos setenta y cinco

Resp $^{\text {ta }} \quad$-Castilla- Muy Poderoso Señor - El oydor a quien se le a nombrado de fiscal

fiscal para esta cauza: en vista de sus autos, y ulteriores representaciones que se han hecho a la ultima que haciendo vista fiscal introdujo, y corre a foxas: dice que estas se reducen por una parte a hauer dos Yndios de la Prouincia de Atacama recusado a todos los vecinos de la Prouincia

Foja 11v

del Tucuman para que cumplieren el auto de fozas, solicitando al mismo tiempo que mientras se ebaquaban las diligencias, para que se nombrase un juez de esta ciudad, se estubiese en ella adonde hauia benido su Corregidor Don Francisco Argumanis, y por otra a hauer el mismo Corregidor impugnado la pretencion de los Yndios, pidiendo antes que los tres que nomina, hallarse actualmente en esta ciudad se les ponga en prision atendiendo a lo que contra ellos resulta de la sumaria que remitio Vuestra Alteza tiene ya tomada prouindencia sobre el primer punto de la recusacion, y asi solo estamos en estado, de que se trate aserca de la entrada del Corregidor, y de la prision de los Yndios. Para lo primero no halla merito bastante el oydor maiormente quando el incombeniente en que se fundan los Yndios de que se puedan con libertad practicar las diligencias que se hallan mandadas, queda reparada con el decreto de foxas, en el que se ordena, que no pase al lugar donde se actuasen estas, ni doce leguas en contorno, cuia disposision debera llebarse a puro, y debido efecto, cumpliendola el Corregidor vajo de un grabe apercevimiento - Para lo segundo es verdad que la sumaria remitida se halla por juez incompetente, en territorio ajeno, y con otros defectos que nesecitan subsanarse con la ratificacion que Vuestra Alteza tiene mandado

Foja 12r

en el auto de foxas. pero atendiendo a ser dichos Yndios los mismo que como principales autores, se deponen a la segunda pregunta de aquella citada Ynformacion. Al hecho del Corregidor de benirse a esta ciudad expresando hauer emprehendido tan largo camino por estar su Prouincia conmobida. Y a que en cauza criminales expecialmente de la presente naturaleza para prosederse a la prision de los reos, bastan presunciones o yndicios los que ya resultan, por los antecedentes que tiene referidos, siente y aun pide en cumplimiento de su obligacion se sirba Vuestra Alteza mandar se proceda a la captura de dichos Yndios; ordenando que con la maior brebedad pase el comicionado que se nombrare a dar perfecto lleno a las ordenes de Vuestra Alteza en los referidos autos auxiliandose para ello en caso nesesario del Gouernador del Tucuman o justicia mas inmediata, a quiens podra Vuestra Alteza mandar que sin la menor escusa ni dilacion le impartan quantos pidiere, gobernandose si, al comicionado, con aquella prudencia suabidad y pulso que se requiere y nececita para mejor cumplir las prouidencias expedidas por Vuestra Alteza. Plata y octubre dies y seis de mil

Auto setecientos setenta y cinco - Riuera - Vistos con lo expuesto por los señores, oydor que hase de fscal, y fiscal Protector General, y los documentos que nuebamente

\section{Foja 12v}

se han presentado. Librese Real Prouicion para que el abogado de la ciudad que nombrare el señor Precidente en conformidad del auto de neinte y ocho de septiembre, pase inmediatamente por la vereda de la prouincia del Tucuman (dandole el Gouernador interino o qualquiera de las justicias della los auxilios que nececitare) al mineral de Yngaguasi, y en el cumpla, y ejecute los autos de primero de junio, y dies y nuebe de agosto ultimos, y en su conformidad procediendo con la deuida circunspeccion y prudencia procurara extinguir qualquier alboroto y tranquilisar los Yndios reduciendolos por los medios que coneptuare por mas oportunos, a que obedescan y respeten a su Corregidor Don Francisco Argumanis, y conseguida la tranquilidad arreglandose a la instruccion que ha presentado el señor oydor que haze de fiscal y a la que nuebamente le remitiese, en la forma acordada, practicara la sumaria de los autores del tumulto, suspendiendo por ahora la aberiguacion de los capitulos que sobre el reparto, y otros asuntos tienen deducidos los Yndios contra el expresado Corregidor sobre la qual se probeera en vista de las diligencias que obrare aserca del dicho tumulto, y para que dicho juez prontamente salga, a practicar esta comision se les notificara a los Yndios que en el termino de ocho dias presisamente cumplan con aprotarle los salarios segun lo ofecieron en el escrito de foxas ciento 
Foja 13r

treinta y seis, y no lo hasiendo en el termino predicho, en atension a que por la muerte del Gouernador Don Geronimo de Matorras, ha sesado en la maior parte el motibo de la recusasion interpuesta por los dicho Yndios; se entienda dicha real prouicion enteramente con la persona que nombrare el señor Precidente de la Prouincia del Tucuman que no sean Don Sinforoso Josef de Rioja y Don Juan Blanco Cruz, para que estas sin perdida de tiempo, y dandole el Gouernador interino o qualquiera de las justicias de dicha Prouincia del Tucuman los auxilios que nesecitare, pase al referido mineral de Yngaguasi, y cumpla, y ejecute todo lo que se tiene ordenado, en este y en los demas citados autos; y librese otra Real Prouicion para que el Corregidor Don Francisco Argumanis prontamente pase por la Prouinsia de Lipez, y dandole el corregidor de ella los auxilios que le pidiere, se restituira a su empleo, en el qual se portara con la suavidad, y madurez, que corresponde, procurando de su parte sosegar y tranquilisar los Yndios, a cuio fin no pasara al mensionado mineral sino se mantendra en los otros Pueblos desempeñando perfectamente las obligaciones de su cargo. Y por lo que resulta de los autos, y se tiene presente librese ceparada Real prouicion para que el Comicionado nombrado haga saber al Doctor Don Miguel de Olmedo, Cura y Vicario del Veneficio de Atacama, que en el termino de la ordenanza presisamente comparesca

Foja 13v

en esta Corte para los efectos que hubiese lugar en derecho, y para que aquel veneficio quede con persona ecleciastica que lo administre Librese otra Real Prouicion de ruego, y encargo al Venerable Dean y Cauildo Sede Vixante para que nombre ecleciastico que cuide de la administracion de aquel Veneficio durante la ausencia del dicho Cura propietario, y dicha Real Prouicion de ruego y encargo, sea igualmente para que el Provisor y Vicario General del Arzobispado substancie la cauza de los capitulos deducidos por dicho Don Francisco Argumanis contra el mencionado Cura Doctor Don Miguel que para el efecto se le tenia remitida por esta Real Audiensia al difunto Muy Reberendo Arzobispo. Y por lo que resulta de la Sumaria recibida por el Comicionado del Gobernador del Tucuman, y demas que se tiene presente el Alguacil maior interino de esta Corthe, con el secreto correspondiente, prendera a los Yndios Aleja Ventura, Ambrocio Mariano, y
Diego Siaris, y los pondra en la carcel publica en la que se mantendran hasta que por esta Real Audiencia se tome prouidencia - dos rubricas- Probeiron y rubricaron el auto de suso los señores Precidente y Oidores de esta Real Audiencia, y fdueron juezes los sñeores Doctores Don Pedro de Tagle Caballero del Orden de Calatraba, y don Josef Lopes Lisperguer oydores en la Plata en treinta de octubre

Foja 14r

de mil setecientos setenta y cinco años- Don Sebastian Antonio Toro- Y hauiendose seguido barios articulos aserca de la prision de los Yndios Alejo Ventura y Diego Siaris, y sobre quien debia costear el Juez para la aberiguacion del tumulto acahesido en dicha Prouincia en cuio estado el nuestro fiscal Protector General presento el escrito que sacado a la letra con el interrogatorio que en el se cita, y auto en su razon probehido es como se sigue - Señor fiscal Protector General - Alejo Ventura Indio principal, y segunda perzona de Gobernador del haciento y mineral de oro, de Nuestra Señora de Loreto de Ingaguasi, terminos del Pueblo de San Pedro de Atacama capital de la Prouincia de este nombre, y Diego Martin Siaris, asimismo Yndio originario y principal del mismo haciento; presos en esta Carcel de Corthe; como mas aia lugar en derecho en los autos con nuestro actual Corregidor de la referida Prouincia, el General Don Francisco Argumanis Fernandez, sobre hauernos sucitado temerariamente cauza, de principales tumultuantes del que tiene figurado, fundado en el alboroto acahesido el dia beinte y ocho de febrero del año pasado de setecientos setenta y cinco, y lo demas deducido en nuestros anteriores escritos Decimos que a llegado a nuestra noticia que el exprezado Corregidor se halla proximo y con el pie al estribo para aucentarse de ciudad con el fin

\section{Foja 14v}

de regresarse de su Prouincia con particular estudio con igual noticia que a adquirido de hallarse en el camino nuestro Gouernador Don Agustin Victorio Ramos con los demas principales del referido nuestro Pueblo conduciendose a esta corte a viar de nuestras defenzas como de benir tambien a contestar con el nuestro Cura Doctrinero el Doctor Don Miguel Geronimo de Olmedo los capitulos siniestros que se les ha puesto por el nominado Corregidor, y este por no haserlo personalmente con los nuestros, ni con dicho Cura A tomado 
el remedio de ausentarse, dejandonos enredados ni hauer cumplido con lo mandado por el auto de veinte y quatro de nouienbre de el pasado, ni con lo prebenido en el beinte y quatro de diciembre por los que se sirbio la justificacion de Su Alteza ordenar se nos debolbiese libremente por dicho Corregidor la bestia que nos quito por bia de embargo despresiando ambas prouidencias, en cuia inteleigensia porque no peresca nuestra justicia, y por conbenir asimismo a nuestro derecho, y a lo principal de nuestra defenza ocurrimos a la piedad de Vuestra señoria por medio de este escrito para que serciorado de su contenido se sirba pedir por la nuestra que el contenido Corregidor no salga en sus pies ni en los ajenos de esta Corthe sin que primero y ante todas cosas bajo de juramento, y sola pena de perjuro

\section{Foja $15 r$}

declare, clara y aviertamente con interbencion de Vuestra señoria del tenor de las preguntas siguientes

Primeramente si es verdad tener en aquel haciento de Yngaguasi a Don Juan Bautista Miner en calidad de juez a prebension o de Comision, y si como tal ejecuta ordenes cobrando sus dependencias, y rescatandole el oro con sus efectos interesandose en todos sus negocios, como en cosa propia diga etcetera

Y si tambien es cierto hauerle escrito una carta dicho corregidor a su comicionado Miner con fecha de quiense de febrero del año pasado de setecientos setenta y cinco notandole por ella de no hauerle remitido, media docena de aquellos viracochas que tenia del numero de cinquenta de ellos, en el citado mineral prebenidos y dispuestos para con ellos prender a no se que pajaros, y con la prision de estos que puesto aseguraba su honor diga- Y consiguientemente declare que para que efecto o con que motibo desde muchos dias antes de el citado dia quince de febrero mando juntar secretamente con dicho Don Juan Bauptista Miner los cinquenta viracochas como igualmente armas de fuego diga etcetera - Y ultimamente diga: si sabe que dia sucedio el alboroto o pendencia que tubieron aquellos viracochas prebenidos por el predicho Don Juan Bauptista Miner con nosotros los micerables Yndios, y que le impartio la

\section{Foja $15 \mathrm{v}$}

noticia del suseso dandole instruccion para que dentrare su perzona, a deshora de la noche con precaucion de nosotros, y a cuia casa fue, a apearse para tomar sus arbitrios; y si igualmente conose a las personas de Don Antonio Contreras, Don Martin Dias, y la de Don Dionisio Chabes, y que relacion tienen con el o con dicho Miner diga etsetera

Y fecha dicha declaracion se ha de serbir la integridad de Vuestra señoria pedir se agregue a los autos de la materia, para que en vista de ella y de la instruccion que protextamos darla a su tienpo se pueda exponer por Vuestra señoria a la justificada atension de Su alteza de clarando nuestra justicia, para que su alta penetracion, mediante ella se sirba ampliarnos la relajacion de esta prision de mas de dos meses graduando nuestra onosensia, y la suma orfandad en que nos hallamos, sin poder por nuestras mismas perzonas viar de nuestra defenza, ni practicar diligensia alguna en cumplimiento de nuestra protexta de aprontar los auxilios para el Juez que haia de pasar de esta corthe a aquellos lugares donde se haia de aberiguar la verdad de dicha cauza. Por tanto, y hasiendo el mas arreglado pedimento- A Vuestra señoria pedimos y suplicamos que hauiendonos por presentados se sirba practicarlo como lo tenemos pedido por ser asi de justicia la que esperamos alcansar, jurando

\section{Foja16r}

lo nesesario en nuestras animas segun derecho no proceder de malicia, y para ello etcetera - Otro si decimos que presisamente cumplida con lo mandado por Su Alteza en los autos citados, y en su conformidad nos entregue nuestra cabalgadura o su importe de los treinta y cinco pesos y con mas los seis pesos de el trensado con que se aseguraba por ser de aprecio

Represen utsupra Alejo Ventura - Diego Martin SiarisMuy Poderoso Señor- El fiscal

tasion Protector General Dice: que teniendo noticia de que Don Francisco

del sr Argumanis intenta ya regresar a su Prouincia se digne Vuestra Alteza

Prot $^{\text {or }}$ mandarle jure y declare al tenor del antecedente interrogatorio como justamente lo solicitan los Yndios capitulantes por esta representacion: pues aunque el presente estado de la cauza se opone a esta diligencia segun el orden judicial, pero promediando la proxima ausencia del citado Argumanis es muy regular se le compele a ella, no defiriendose a su disposision sino, en lo faborable, y quedando citado para la prueba en caso de su negatiba Plata

Auto y enero beinte y quatro de mil setecientos setenta y seis - Castilla- Vistos hagase como lo pide el señor fiscal Protector General, y en su 
conformidad el Comicionado que se nombrare para la aberiguacion del tumulto acahesido en la Prouincia de Atacama hara que Don Francisco Argumanis Fernandes, jure y declare al tenor del interrogatorio

Foja 16v

presentado por los Yndios $=$ dos rubricas $=$ Probeieron y rubricaron el auto suso los señores Precidente y oidores de esta Real Audiencia, y fueron juezes los señores Doctores Don Pedro de Tagle Caballero del orden de Calatraba, y Don Josef Lopes Lisperguer, Oydores en la Plata en beinte y ocho de febrero de mil setecientos setenta y seis años Don Sebastian Antonio Toro-, Despues de lo qual en vista del informe que dirijio a la dicha nuestra Real Audiencia el Casique Don Agustin Victorio Ramos, y de lo que expucieron el nuestro oidor que ejercia de fiscal y fiscal Protector General se probeio el auto que sacado a la letra, con el de dos del presente y nombramiento hecho por el nuestro Precidente es como se sigue- Vistos con lo expuesto por los Señores fiscal, y fiscal Protector General: Dando fianza del haz a satisfaccion del Escribano Publico de Camara de guardar carceleria en esta ciudad, y de presentarse diariamente al señor juez semanero, los Yndios Alejo Ventura Ambrocio Mariano, y Diego Siaris, se les dara soltura de la prision en que se hallan. Y respecto de que hasta ahora no se a nombrado el comicionado que se prebino por auto de treinta de octubre del año antecedente, y expresar los Yndios por los motibos que representan, no poder por ahora aprontar los abios nesesarios para la conduccion de dicho juez, atendiendo

Foja $17 \mathrm{r}$

a la grabedad de la materia, y a que no se dilate la aberiguacion mandada. Pasense los autos al señor Precidente para que haga el nombramiento del comicionado, al qual por ahora, el receptor de penas de camara, le entregara dosientos pesos del ramo de gastos de justicia con cargo de reintegro de los que resultaren culpados despachandose para ello el correspondiente libramiento. Y dicho comocionado no solo practicara la aberiguacion prebenida en el citado Auto de treinta de octubre, sino que tambien hara que reconosiendo el Casique Don Agustin Victorio Ramos su informe de dies y ocho de enero del presente año, y confesando hauerle hecho produsca informacion sobre todos los capitulos del citado informe el qual para este efecto se le entregara original quedando testi- monio, prebiniendosele al dicho juez que reciuidas las sumarias que se hallan mandadas cobre por todo rigor de derecho de los que resultaren culpados los expresados dosientos pesos, para que se reintegre el dicho ramo de gastos de justicia, a cuio fin los remitira a poder del receptor de penas de Camara conclusas las diligencias las que remitira serrada y selladas a esta Real Audiencia con el respectibo informe - dos rubricasProbeiron y rubricaron el auto de suso los señores Precidente y oidores de esta Real Audiencia y fueron Jueses los señores Doctores Don Pedro de Tagle Caballero del orden de Calatraba, y Don Josef Lopez Lisperguer Oydores en la Plata en once de marzo

Foja $17 \mathrm{v}$

de mil setecientos setenta y seis años- Don Sebastian Antonio Toro- Vistos pasense estos autos al señor Precidente para que nombre juez que con la posible brebedad pase a la Prouincia de Atacama para el puntual cumplimiento de los autos de primero de junio, dies y nuebe de Agosto, treinta de octubre del año antecedente, y once de marzo del presente; y fecho respecto de tener pedidos estos autos, el Doctor Don Miguel Geronimo de Olmedo, se le entregaran por el termino ordinario para que use de su derecho- una rubrica- Probeiron y rubricaron el auto de suso los señores Precidente y oidores de esta Real Audiensia, y fueron juezes los señores Doctores Don Pedro de Tagle Caballero del orden de Caltraba oydor en la Plata en dos de maio de mil setecientos setenta y seis años-

Nombra ${ }^{\text {to }}$ Don Sebastian Antonio Toro- Plata y maio catorce de mil setecientos setenta y seis añosNombrase a Don Nicolas Leon de Ojeda, y en su defecto a Don Philiberto Mena_ una rubrica- Hizo y rubrico el nombramiento antecedente el señor Don Ambrocio de Benauides Coronel de Ynfanteria de los reales ejercitos de Su magestad, y Precidente de esta Real Audiencia en la Plata en el dia mez, y año de su fecha- Don Sebastian Antonio Toro- En cuia conformidad fue acordado que debiamos mandar dar esta nuestra carta, y Prouicion Real en la dicha razon, y tubimoslo por bien por la qual os mandamos a voz Don

\section{Foja 18r}

Nicolas Leon de Ojeda, y en vuestro defecto o lejitimo impedimento a don Philiberto Mena, perzona nombrada por el nuestro precidente que siendo con esta requerido o que de ella os conste en qualquier manera que sea, 
beais los autos probeidos por los dichos nuestro Precidente y Oidores que de susos ban incertos, y lo guardeis cumplais y ejecuteis segun su tenor y forma. Y en su cumplimiento dandoos las justicias de la Probincia del Tucuman, los auxilios nesesarios, pasareis prontamente a la de Atacama, y con la debida refleccion, y madurez procurareis por los medios que os dictare la prudensia, tranquilisar los Yndios para que cumplan con sus obligaciones, obedeciendo, y respetando a su Corregidor Don Francisco Argumanis, lo que fecho, y conseguida la tranquilidad de la Prouincia, resibireis sumaria ynformacion para la aberiguacion de los autores del tumulto prendiendo a los que resultasen culpados, y principales autores de la sublebacion, y embargandoles sus vienes, los remitireis presos a su costa a esta Real Carcel de Corthe con buena guarda y custodia, guardando en todo los citados autos probeidos por la dicha nuestra Real Audiensia, y arreglandoos a la instruccion que se os dirije presentada por el nuestro Oydor que ejercia de fiscal: suspendiendo por ahora la aberiguacion de los capitulos que sobre el reparto y otros asuntos tienen deducidos los Yndios contra el exprezado Corregidor sobre

\section{Foja 18v}

la qual se probera en vista de las diligencias que obrareis aserca del tumulto y concluso lo referido hareis que el citado Corregidor, jure y declare al tenor del ynterrogatorio que igualmente ba incerto. Lo que executareis y cunplireis asi presisa, y puntualmente pena de la nuestra merced, y de quinientos pesos ensaiados para la nuestra Real Camara, vajo de la qual mandamos a qualquiera nuetsro Escribano Publico o Real, y a su falta a perzona de cepa ler [sic] y escribir, que ante dos testigos os la lea intime, y notifique, y haciente la diligencia que hisieze, para que conste, y cepamos como se

21 Mayo cumple nuestro mandado Dada en la Plata en beite y uno de maio de mil

1776 setecientos setenta y seis años- Ambrocio de Benauides- Don Josef Lopes Lisperguer- Don Ramon Riuera- Yo Don Sebastian Antonio Toro Escribano de Camara del catholico Rey Nuestro Señor la hize escribir por su mandado, y con acuerdo de su Precidente y oidoresReguistrada Juan de Mallauia-

Obede Por el Gran Chansiller Juan de Mallauia- En la ciudad de Salta en siete dias

cimiento del mez de octubre de mil setecientos setenta y seis años el Maestre de Campo Don Nicolas Leon de Ojeda hauiendo sido requerido con la Real prouicion antecedente por el Casique Don Agustin Ramos acompañada de una instruccion del Señor fiscal Protector hallandose actualmente en cama enfermo, y purgado dijo: que en atension a la puntualidad con que se debe ejecutar

\section{Foja 19r}

lo mandado por $\mathrm{Su}$ alteza, y embarasarselo su actual enfermedad pasese su ejecucion y cumplimiento al segundo nombrado Don Philiberto de Mena por comicionado y que en quanti a lo beridico de su impedimento no obstante lo notorio de ella, diese maior abundamiento certificacion de ello el medico de su asistencia que lo es Don Manuel Ysidro Carmona titular de esta ciudad, y asimismo el presente escribano como que lo certifico en la forma que haia lugar en derecho Yo dicho escribano ser constante que el mensionado Señor Comicionado haze dias se halla doliente e indispuesto en cama: y lo firmo su merced de que doy fe- Nicolas Leon de Ojeda- Ante mi Gil Ynfante Escribano Publico. Salta ocho de octubre de mil setecientos setenta y seis años- Yo el Licenciado Don Manuel Ysidro de Carmona medico titular de esta ciudad certifico en la forma que por derecho pueda como el maestre de Campo Don Nicolas Leon de Ojeda, se halla indispuesto y padeciendo un Perinu emori, acompañada de fiebre, y con esputo espomoso de prolija, y dificultosa curacion, la qual estoy actualmente ejercitando metodicamente, y de su pedimento doy la presente, bajo la grabedad del juramento que tengo prestado a la recepcion de mi facultadLicenciado Manuel Ysidro de

2o Carmona y Adaliv- En la ciudad de Salta en dies de octubre de mil setecientos setenta y seis años Don Philiberto de Mena vecino de ella. Hauiendo visto

\section{Foja 19v}

la Real Prouicion antecedente dijo: que acatando la Suprema confianza de su Alteza para el desempeño y cumplimiento de su justificado mandado Suplica reberentemente se le exsima por los justos, y notorios impedimentos que tiene el primero, que siendo cierto el adolecimiento accidental certificado del primer Comicionado por cuio motibo se halla excusado le prefiere el havitual que padece el suplicante respecto a que en todo el año no gosa de perfecta salud expecialmente en el verano por predominar en su compleccion el humor sanguineo ardiente que no le permite ajitacion de Caballeria y siempre o quando se le a ofrecido salir de esta ciudad a una corta 
distancia a respirado la forsosa consequensia de una copiosa fluccion de sangre de las almorranas encanceradas conque se halla por lo qual nececita de un prolijo cuidado, medecina y sosiega sin afoleo a consejo de medico. Lo segundo ser asimismo notorio los cortos medios que tiene para sufragar los conciderables costos que ofrece la larga distancia a donde se ha de practicar la actual diligensia, desamparando las presisas obligasiones de su muger y familia que vive a expenzas de su perzonal trabajo. Lo tercero hallarse a la razon impedido en la actuacion de barios asuntos de Real Hazienda como defensor que es de ella, y piden pronto expediente: e igualmente entendiendo en la laboriosa tarea de arreglar el archibo de Gouierno asosiado de uno de los juezes ordinarios por Comision

Foja 20r

que a su partida de esta ciudad a la vicita de fuertes lo dejo el actual Gobernador, por cuios justificados motibos se halla inavilitado de poder dar como lo desea el debido cumplimiento a esta comicion, y que sino obstante no los tubiere su Alteza por bastante esta pronto a sacrificarse rendidamente a quanto fuere de su superior agrado, y lo firmo conmigo de que doy fe- Philiberto de Mena- Ante mi Antonio Gil Ynfante Escribano Publico-

Ynstruc $^{\text {on }}$ Ynstruccion dada para el juez que pasare a la Prouincia de Atacama, debera cumplir con el auto de la Real Audiencia de dies y nuebe de Agosto del presente año en quanto a lo que trata de Corregidor, tranquilidad y obedinecia de los Yndios. Pasara al Pueblo de Yngaguasi, y pidiendo de Don Josef Castañares los autos que hubiere obrado, aberiguara los hechos notificando antes de principiar la cauza al Corregidor que no pase a dicho Yngaguasi no doce leguas en contorno todo el tiempo que durare la comision, y procedera a examinar los testigos en la manera siguiente

Primeramente si saben el motibo o cauza que interbino para el movimiento que se experimento el dia de carnestolenda

Yten quienes fueron los principales autores

Yten si saben o han oydo decir que los Yndios hubiesen sido seducidos por alguna persona y qual sea esta

Yten quales fueron los hechos que se perpetraron los Yndios, y quales los españoles expecificandose con claridad, y distinsion lo susedido

Yten que movimientos hisieron los Yndios
Fojas 20r

quando paso el Corregidor a Yngaguasis y quales quando vieron que se retiro al Paraje de los Molinos. Lo qual concluido prendera a los que resultaren grabemente culpados, remitiendolos a esta Carcel de Corte segun se halla mandado por la Real Audiencia embargandole sus vienes, depositandolos en perzona segura Plata y Agosto beinte y seis de mil setecientos setenta y cinco- RiueraConcuerda este traslado con la instruccion original de su contexto que esta, y se halla en los autos seguidos sobre el lebantamiento acahesido en la Prouincia de Atacama, con la que corregi y conserte a que en lo nesesario me refiero. Y para efecto de dirigir al juez comicionado para la aberiguacion del dicho lebantamiento en virtud de lo mandado por los señores Precidente y oidores de esta Real Audiencia hize sacar el presente en la Plata en beinte y cinco de maio de mil

Auto setecientos setenta y seis años. Don Sebastian Antonio Toro- Vistos guardense y cumplanse los autos de primero de junio, diez y nuebe de agosto, y treinta de octubre del año de setecientos setenta y cinco, y el de onse de marzo del año siguiente. $Y$ en su conformidad dandose por excusados a los juezes nombrados Don Nicolas Leon de Ojeda, y Don Philiberto Mena, pasense estos autos al Señor Precidente para que de la prouidencia del Tucuman nombre perzona para que sin replica ni pretexto alguno cumpla y ejecute

Foja 21r

el contenido de los citados autos, sin que se experimenten, las dilaciones que hasta aqui con grabe perjuicio de los Yndios, y de la cauza publica - una rubrica- Probeiron y rubricaron el auto de suso los señores Precidente y oidores de esta Real Audiencia, y fue Juez el Señor Doctor Don Josef Lopez Lisperguer Oydor en la Plata en siete de mayo de mil setecientos setenta y siete años. Don Sebastian Antonio Toro- En dicho dia mez y año Yo el Escribano pase noticia del auto antecedente al Señor fiscal Protector

Escrito General de que doy fe. Toro- Muy Poderozo Señor- Alejo Ventura, y Diego Martin Siaris Yndios principales, y tributarios del haciento de Yngaguasi jurisdiccion de la Prouincia de Atacama, en los autos con el General Don Francisco Argumanis Fernandez, sobre la falsa, y temeraria expecie, que se nos ha sucitado de ser tumultuantes nuestras infelices personas ( $\sin$ apartarnos de la Real Proteccion) Decimos: que por auto de siete de maio de este presente año, se halla mandado por Vuestra 
Real perzona, el que se lleben los autos de la materia al señor Precidente para que por su señoria se nombre una persona de los de la Prouincia del Tucuman para que este con arreglo a los autos que en el se citan pase al dicho haciento de Yngaguasi a practicar la aberiguacion de la cauza en los terminos que en ellos se prebiene cuia diligencia no se a podido berificar

Foja 21v

a mas de un año que nos hallamos presos guardando el tenor del auto de quinse de marzo de setecientos setenta y seis. Despues del padecimiento, de prision de cinco meses y mas de rejas para dentro en esta Carcel de Corthe sin embargo de hauerse nombrado de los de aquella misma Prouincia a Don Nicolas Leon de Ojeda, y por defecto de este a Don Philiberto Mena, de cuio poder despues de seis meses, se nos bolbio la Real Prouicion sin diligencia alguna, en grabe perjuicio nuestro. Y conciderando que lo propio pueda suceder por no tener alli dinero para conducirlo ni quien pueda ajitar este negocio como nuestras mismas perzonas. suplicamos a la Soberana piedad de Vuestra Alteza, se digne mandar que la dicha aberiguacion, y auto probeido para este efecto se entienda en el nuebo Corregidor de aquella Prouincia el General Josef Maria Paniagua, que se halla posecionado en su empleo, quien podra desempeñar el asunto con la perfeccion que corresponda por hallarse imparcial conosidamente aquel Juez debolbiendosele a este Real Prouicion agregandose a ella en testimonio lo ultimamente resuelto por Vuestra Alteza: por tanto y haciendo el pedimento mas conforme- A Vuestra Alteza pedimos y suplicamos, que hauiendonos por presentados se sirba de prober mandando como llebamos pedido por ser de justicia, y juramos en nuestras animas lo nesesario en derecho y para ello

Foja 22r

etsetera- Alejo Ventura- Diego Martin SiarisEn la Plata en catorce de junio de mil setecientos setenta y siete años ante los Señores Precidente y oidores de esta Real Audiencia en la de relaciones represento cita PeticionLos dichos Señores mandaron que la aberiguacion mandada practicar con el nuebo Corregidor de la prouincia de Atacama Don Josef Maria Paniagua, y para su ejecucion se le entregara, a estas partes la Real Provicion librad agregandose este escrito con su probeido a dicha Real Prouicion testimonio, como igualmente de las demas prouidencias-
Don Sebastian Antonio Toro- En la Plata en catorce de dicho mez y año. Yo el Escribano pase noticia del decreto antecedente al señor fiscal de que doy fe Toro- Concuerda este traslado con el escrito auto, y decreto originales de su contexto, que en caso nesesario me refiero; y para efecto de entregar a la parte de los Yndios hize sacar el presente en la Plata en dies y seis de junio de mil setecientos setenta y siete años- Don sebastian Antonio Toro -Yngaguasi dies y ocho de septiembre de mil setecientos setenta y siete- Por presentado el despacho Prouicion Real, librado por los señores Precidente y oidores de la Real Audiencia del distrito, su fecha en la Plata, a catorce de junio del presente año de mil setecientos setenta y siete, con la instruccion que le acompaña dada por el señor oidor que hizo de fiscal, la que

Foja 22v

se agregara a dicho Real despacho para proceder por ella, a la aberiguacion de lo que se ordena. El qual tomandolo $\mathrm{Su}$ merced en las manos, puesto en pie y destacado, lo bezo y puso sobre su cabeza, como carta de su Rey, y Señor natural, y en su execucion, y cumplimiento, mando se guarde cumpla, y ejecute en todo y por todo, segun y como prebiene. Y atento a que en el Pueblo de Atacama cabeza de esta probincia se presento ante su merced el Gobernador ynterino de naturales de ella Don Agustin Victorio Ramos hauiendo demostracion de este despacho prebiniendo lo exiviria y presentaria en toda forma en este jusgado luego que se llegase a este Aciento y mineral: en cuia virtud le manda su merced al dicho Gouernador de Yndios, a prontar cinco mulas de silla, y ocho de carga para los Bagajes, y conduccion hasta este haciento prebiniendole que los gastos del camino corrian de quenta de su merced: en vista de lo qual el referido Gouernador puso de manifiesto las citadas mulas, y salio su merced del referido Pueblo de Atacama el dia beinte y seis de agosto, y caminando se hizo forsosa alguna demora a cauza de los intemperies del tiempo

Foja 23r

segun lo riguroso de la estacion de el; por lo que se llego a este mineral el dies y seis de septiembre respecto de todo lo relacionado dijo su merced deuia de mandar, y mando que arreglado a lo resuelto en los autos prescriptos que constan en este Real Despacho se formalise la comision que se le ordena a $\mathrm{Su}$ merced dando principio primariamente ante todas cozas, a la Pacificacion, quietud, y so- 
siego de animas de los que se hallasen conmovidos, procurando i con prudencia, suavidad y zagasidad, reducirlos a la Paz, y recosimiento, como fieles vasallos del Rey nuestro Señor (que Dios Guarde) a quien debemos obedecer todos con la maior beneracion, y sumicion, y en su Real nombre, a las justicias que Giuiernan sus Reynos y prouincias. Para lo qual, se destina el primer dia de fiesta, despues de la misa maior en la Plaza delante de la Iglecia, a fin de que a todo el concurzo de perzonas, asi españolas como naturales, les conste lo resuelto y determinado por los Señores Precidente y Oidores de dicha Real Audiencia, de lo qual y el semblante de todos los que concurriesen se pndra diligencia a continuacion. Y mediatamente a que el General Don Francisco de Argumanis Fernandez Corregidor y justicia mayor que fue de esta Prouincia a quien ha subsedido Su merced: salio de ella poniendose en camino para la ciudad de Lima con toda su familia, se omita el requicito de notificacion, y demas diligencias que se exprezan, y ordenan en este Real despacho

Foja 23v

como asimismo lo prebenido en el auto de dies y nuebe de agosto del año pasado de setecientos setenta y cinco; sobre que el Doctor Don Miguel Geronimo de Olmedo, Cura propio del Beneficio de Atacama, benda los dos Yngenios o trapiches que hizo fabricar en el Paraje nombrado los Chorrilllos, executandolo dentro de tres meses a perzona secular; atenta a que con motibo de lo acahesido, han quedado desamparadas estas minas, y no ay oy en este aciento minero español que la trabaje, por cuio motibo remiran en la presente los citados trapiches sin usos ni aplicacion alguna, y por consiguiente de ningun balor ni efecto no hauiendo perzona que los nesecite, ni apetesca. Y en quanto a lo que se ordena juntamente en el citado auto de dies y nuebe de agosto de setecientos setenta y cinco, serca de que se recoja la prouicion Real que por dicha Real Audiencia se le libro, y las diligencias que en su virtud hubiese practicado Don Josef de Canisares; y el testimonio de la sumaria recivida por Don Sebero de Yrasmendi de orden del Gouernador del Tucuman para notificar de nuebo uno y otro saquese tanto de este auto, y remitase con carta por este jusgado al citado Don Josef de Caisares a efecto de que cumpliendo con lo mandado por dicha Real Audiencia lo remita y entregue todo cerrado y sellado, con el mismo propio conductor sin la menor demora para en su vista tomar las prouidencias
Foja 24r

que estan prebenidas, y sean mas conforme a derecho, entregandole la referida carta al Casique Gobernador de naturales, para que apronte cañari con perzona de toda satisfaccion que la condusca, firmando el dicho Gouernador el respectibo recibo en estos autos para que conste. $\mathrm{Y}$ en punto de lo ordenado en los autos de primero de junio de setecientos setenta y cinco, y once de marzo de setecientos setenta y seis, sobre que se aberiguen todos los hechos que se contienen en la representacion que dirijio a la referida Real Audiencia el casique del Pueblo de San Pedro de Atacama, Don Agustin Victorio Ramos, resibiendo para el efecto la respectiba sumaria Ynformacion prendiendo a todos los que resultasen culpados: y que reconosca el referido Casique su informe de dies y ocho de enero del citado año; y confesando hauerlo hecho produsca informacion referida a sobre todos los capitulos del citado informe: no constando este en estos despachos, se le notifique al referido Casique sobre esta materia para que le conste, y use de su derecho como viere que le conviene. Y fecho todo, y tranquilisados los animos segun queda expuesto, pasese a la aberiguacion de los hechos tocantes a la sublebacion, y tumulto perpretado sugeta materia prendiendose a los que resultasen culpados, los que se remitiran presos a su costa a buena guarda y custodia a la Real Carcel de Corte de la Ciudad de la Plata. Y conclusa esta sumaria, traiganse los autos a la vista para dar prouidencia y cumplir

Foja 24v

con lo demas que se halla ordenado. asi lo probeio decreto mando y firmo Su merced el Señor Don Josef Maria de Paniagua Cosio y Teran, Comandante de Caballeria, teniente de Capitan General, Jues de Vienes de difunto, Alcalde maior de minas y registros, jues pribatibo de penas de Camara de Comisos y Alcabalas, Corregidor y Justicia maior por su magestad de esta Prouincia de Atacama, su termino y jurisdiccion actuando en ella judicialmente, en este haciento y mineral, ante si y testigos a falta de Escribano Publico, ni Real- Don Josef Maria Paniagua y Cosio- Don Josef de Nigelperizena- Don Geronimo de Amenabar- En el Aciento y mineral de Yngaguasi, jurisdiccion de la Prouincia de Atacama en beinte y un dia del mez de septiembre de mil setecientos setenta y siete años. Yo Don Josef Maria de Paniagua Cosio y 
Teran Comandante de Caballeria teniente de capitan General, Corregidor y Justicia maior en esta cauza, en virtud de lo por mi mandado en el decreto de obedecimiento que antecede, mande a los Alcaldes, y demas Justicias de este mineral, prebiniesen al Pueblo de mi orden, que despues de misa se esperasen todos en la Plaza, delante de la Yglecia, y hauiendose concluido el Santo Sacrificio, sali de el Templo a la Plaza donde vi un gran numero de perzonas asi españolas como naturales: a quienes prebiniendoles cilencio les expuse a lo que se dirigian mis palabras, viniendo de Paz, en cumplimiento de lo mandado, y resuelto

\section{f $25 \mathrm{r}$}

por los Señores Precidente y oidores de la Real Audiencia de la Plata; solo a adbertirle a todos, y con especialidad a los Yndios la grande obligacion que tienen de ser fieles, agradecidos, obedientes y humildes Vasallos al Rey de España nuestro Soberano, y señor Natural, que a costa de la Sangre derramada de sus Españoles, ha extendido los estandartes de la fe hasta estos bastos Dominios que la divina omnipotencia le ha consedido a fin de que tenga la Gloria de encaminar a estos neofitos a su Patria Celestial, sacandolos de las tinieblas, del abismo en que como Gentiles vivian de antes; para lo qual, y que lograsen los pribilegios de Españoles, y no ignorasen las claras y Divinas luces del Evangelio, les ha embiado a estos Reynos y prouincias, el gran Monarcha Catolico de España nuestro señor Prelados Ilustrisimos Arzobispos y Obispos, Religiones y Curas que los confiesen, y enseñen para merecer despues de esta vida, la felicidad incomparable de la gloria eterna a que todos debemos aspirar, despues que salgamos con la muerte de este Valle de micerias, y trabajos, dondenos hallamos desterrados. Y que quedasen enterados y ciertos todos, que el que tubiese atrebimiento desde oy en adelante a faltar a la debida obediensia al Rey nuestro amable Soberano y Señor Natural, y en su Real nombre a las Justicias, Gobernadores y Corregidores que Gouiernan estas Prouincias, expresando en juntas y tumultos que estas tierras no son del Rey de España, y que salgan los Españoles de ellas desde ahora para entonses, los declaro por traidores al Rey y su Real

Foja25v

Corona; protextando dar parte a Su magestad para que en atension a los lebantamientos, tumultos y alborotos de esta Corta Prouincia de
Atacama, se digne y resuelba su Magestad mandar que todos los Yndios de ella baian a trabajar perpetuamente durante sus vidas, a las minas de Potosi, y que sacandose de ellas, otro tanto numero de perzonas de todos sexsos, bengan a Poblar esta Prouincia de nuebo, haciendose dueños de Ganados, Casas, Estancias, y demas que oy poseen. En cuia inteligencia, ofrecieron todos ser muy obedientes desde el dia de oy, y con semblantes alegres, repitieron viva el Rey nuestro Señor con cuia Real palabra se finalizo. Asi lo expreze, y di a entender usando de aquellos terminos medios, que mi prudencia, y escasa capacidad me dicto: y para que conste lo pongo por diligencia que firme con todos los circunstantes que se hallaron presentes a falta de Escribano Publico, ni Real- Don Josef Maria de Paniagua y Cosio- Josef de Migelperizena- testigo Ygnacio QuiñonesGeronimo de Amenabar- Jacinto FernandezBlas Lopez de Pieod- Josef Irribarren- Antonio Borque- Manuel Luengo- Agustin Victorio Ramos- Yngaguasi treinta de Septiembre de mil setecientos setenta y siete- En este Aciento y mineral de Yngaguasi, Jurisdiccion de la Prouincia de Atacama, siendo como a horas de las dies de la mañana de este dia se le entrego en este jusgado, al Casique Gouernador Ynterino Don Agustin Victorio Ramos el pliego serrado con el testimonio del decreto del obedecimiento

Foja 26r

que antecede, y carta adjunta para que Don Josef de Canisares, como esta mandado, hauiendole leido antes de serrarlo uno, y otro, a dicho Casique; quien firmo aqui su recibo, $\mathrm{y}$ para que conste se anota y firma poniendolo por diligencia- Paniagua- Don Agustin Victorio Ramos- En este Aciento y mineral de Yngaguasi en tres dias del mez de octubre de mil setecientos setenta y siete años. Yo el general, Coorregidor, y Justicia maior por su magestad de esta Prouincia Juez para lo que se manda en este despacho; en virtud de lo mandado en el decreto de obedecimiento de el, hize parecer en este mi Jusgado al Casique Ynterino de esta Prouincia de Atacama, a quien le hize saber y entender lo resuelto por los Señores Precidente y Oidores de la Real Audiencia del Distrito, en los autos expedidos, en primero de junio de setecientos setenta y cinco, y once de marzo de setenta y seis sobre sus Ynformes presentados para que use de su derecho, lo que oyo, y entendio,

1a de y para que conste lo firme- Paniagua - En el Aciento y mineral de Yngaguasi, 
claracion Jurisdiccion de la prouincia de Atacama, en dies dias del mez de octubre de mil setecientos setenta y siete años. Su merced el Señor Don Josef Maria e Paniagua, Cosio, y Teran, Comandante de caballeria, teniente de Capitan General Juez de vienes de difuntos, Alcalde maior de minas y registros, Juez pribatibo de penas de Camara de Comisos, y Alcabalas Corregidor, y Justicia maior por su magestad de esta dicha Prouincia, juez en estos autos

Foja 26v

en virtud de lo mandando en ellos, y de lo probeido en el decreto de obedecimiento, hizo compareser ante si, y los testigos de actuacion, a falta de Escribano a Don Bernardo de Cordoba, recidente en este Aciento, y Vecino del Valle de San Carlos, Prouincia del Tucuman; de quien su merced recibio juramento, que lo hizo a Dios nuestro Señor, y una señal de Cruz segun forma de derecho bajo de cuio cargo prometio decir berdad, en todo lo que supiere, y le fuere preguntado, y siendolo al tenor de la instruccion, que acompaña el Real despacho que antecede, que se halla a foxas beinte y tres

A la primera pregunta dijo: que ignora la cauza o motibo del lebantamiento de los Yndios de la Prouincia de Atacama, en este mineral por no hauerse hallado en el, declarante

A la segunda pregunta dijo: se remite a lo que tiene dicho en la respuesta antecedente

A la tercera pregunta dijo: que lo que puede decir por hauerlo presensiado es; que hauiendo benido embiado el declarante a este mineral, en el tiempo del tumulto, a ber y saber en que citado se hallaba este aciento, y si permanecian gentes en el, o se miraban los Yndios fugitibos, y que procurase saber con sagacidad, que motibo hauian benido para el alsamiento, y que perzona los conmovio a el; se vio presisado el que declara, luego que llego aqui a despachar un propio al Paraje o quebrada llamada los Ratones, donde supo paraban todos, por noticia que de ello tubo, de dos o tres Yndias

\section{Foja 27r}

viejas que encontro solamente en este Aciento y mineral. Que a los tres dias, bolbio el propio que despacho biniendo acompañado de dies y seis, o dies y siete Yndios, traiendo por Capitan y Cabeza a uno llamado Domingo Vicente, que a la razon se hallaba de Alcalde, a quien tomando la voz con algunos de su comitiba, dijo: al que declara: que no hauiendo sido seducidos por nadie para lebantarse que ellos de su mutuo propio lo hauian executado

A la quarta pregunta dijo: que lo que supo, y ha oydo decir es, que todos los mineros, es pañoles y mugeres, los unos salieron huyendo de aqui y a las otras se las llebaron los Yndios a los cerros pricioneras

A la quinta pregunta dijo: que no le consta cosa alguna de lo que se le pregunta. Que todo quanto a dicho, es lo que sabe, a visto y presenciado, y lo que puede decir como berdad en cargo de juramento que fecho tiene, en que se afirmo y ratifico siendole leida esta su declaracion que no le tocan las Generales de la ley, que es de edad de quarenta y cinco años, poco mas o menos, y lo firmo con su merced, y los testigos con quien se actua judicialmente a falta de Escribano - PaniaguaGeronimo de Amenabar -

2 Bernando de Cordoba- Josef de Migelperizena- En el Aciento y mineral de Yngaguasi en trece dias del mez de octubre de mil setecientos setenta y siete años. Su merced el señor Don Josef Maria de Paniagua, Cosio y Teran, Comandante de Caballeria, teniente de Capitan General Juez de

Foja 27v

Vienes de difuntos, Alcalde maior de minas, y Registros, Juez Pribatibo, de penas de Camara, de Comisos, y Alcabalas, Corregidor y Justicia maior por su Magestad, de esta Prouincia de Atacama su termino y Jurisdiccion, Juez en estos autos . En prosecucion de esta sumaria Ynformacion hizo comparecer ante si y testigos a falta de Escribano en este su Jusgado , a don Jorge Pirola Vecino de la ciudad de Arequipa, recidente, en este haciendo, y mineral, de quien su merced recibio juramento, que lo hizo a Dios nuestro Señor, y una señal de Cruz segun derecho, so cuio cargo prometio decir berdad, en todo lo que supiere y le fuere preguntado; y siendolo al tenor de las preguntas, que constan en la Ynstruccion dada por el Señor fiscal Oydor, que esta a foxas beinte y tres de estos autos: A la primera pregunta dijo: que con motibo de hauerse hallado en este mineral el declarante, el dia de Carnastoledas que fue quando se experimento, el alzamiento y tumulto de los Yndios contra los Españoles, y mineros, que aqui avia; vio el que declara que Don Antonio Contreras, minero salio de su casa tras un Yndio llamado Diego Siaris, a quien le alcanzo dos puñaladas en un braso: Que no oyo el declarante las razones que dicho Contreras le desia al Yndio, y asi no pudo 
enterarse del motibo o probocacion con que este enardecio el caso, para que lo hubiesen herido; pero vio que inmediatamente acudieron mas de Cinquenta Yndios que estaban junto a la Capilla, y otros tantos en otra casa

\section{Foja 28r}

mas alla, y oponiendose a todos los Españoles que se hallaban juntos con dicho Contreras, en la Casa de Don Domingo Chabes mercader con generos aqui; empesaron a tomar piedras grandes, tirando con toda fuerza a la puerta de dicha casa donde ser retiraron serrandose por de dentro todos los referidos Españoles, quienes viendo la temeraria accion de los Yndios, y que su empeño era haser la puerta pedasos, reconociendo y advirtiendo al mismo tiempo, que una tropa de Yndios, empesaban a destechar, la casa, entreabrieron la Puerta los Españoles hasiendo Campo con algunas bocas de fuego de que salio un Yndio lastimado para poder salir a fuera huyendo, como lo lograron; pero apenas salieron quando los Yndios los maltrataron a pedradas y siguiendo a Don Juan Bautista Miner, y a Don Domingo Chaves, se refugio este en una Casa, donde cercandolo la muchedumbre de Yndios, oyo el declarante que dijeron todos peguenle fuego, para que no se escape; y que entonses el que declara procuro esconderse en una mina para librarse del riesgo de muerte, que amenasaba a todos los Españoles; donde estubo hasta la noche, que salio, y se fue a su Casa; y por la mañana supo que Don Juan Miner se hauia aucentado de este mineral huiendo a pie como tambien Don Antonio Contreras, y que los Yndios hauian cojido a Don Domingo Chaves a quien maltrataron dandole con piedras grandes en la cabeza y la cara, y de esta forma casi muriendo, lo amarraron y llebaron preso, al

\section{Foja 28v}

Paraje que llaman el agua Salada

A la segunda pregunta dijo: que oyo decir que el general Don Francisco de Argumanis. hauia escrito una carta al dicho Miner, y al citado Chabes dandoles orden de prender a algunos, y que por esto fue el lebantamiento, echando los Yndios la culpa a estos dos como a autores contra ellos; cuia carta trajo Pasqual Pinto Yndio, y otra despues- A la tercera pregunta dijo: que no sabe nada tocante a esta tercera pregunta que se le hase

A la quarta pregunta dijo: que se remite a lo que deja dicho en la primera que fue, lo que vio y presencio, y que no sabe mas

A la quinta y ultima pregunta dijo: que no sabe nada de lo que ocurrio quando el Corregidor Francisco de Argumanis, vino a este mineral con la noticia que tubo del lebantamiento de los Yndios, porque en aquel entonses, estaba el que declara fuera de este haciento en la jurisdiccion del Tucuman - Y añade que oyo decir en el Valle de Calchaqui, que el referido Corregidor escribio tercera carta, a este mineral, ordenandole al dicho Miner registrase a Alejo Ventura, por si le podia hallar alguna carta o papel del Cura de Atacama. Que tambien, oyo decir, que los Yndios de este haciento, se retiraron todos llebandose por fuerza al paraje u Quebrada que llaman los Ratones a y todos los Españoles y mugeres que quedaron a qui, luego que supieron que benia el Corregidor a entrar de noche

\section{Foja 29r}

que antes de Carnastolendas, mando llamar Don Juan Bautista Miner Comicionado que era aqui, de dicho Corregidor, para el cobro de alcabalas, al declarante, y otros Españoles y preguntandoles a cada uno, que armas tenian, les dio orden que estubiesen prontos y prebenidos para quando los llamase, porque tenia que practicar una diligencia de orden de dicho Corregidor. Que es todo lo que a visto, presenciado, y oydo, y lo que puede decir, como berdad, en cargo del juramento que fecho tiene, en que se afirmo y ratifico siendole leyda esta su declaracion, que no le toxan las Generales de la ley, que es de edad de beinte años, y lo firmo con su merced y los testigos con quien actua judicialmente a falta de Escribano -Paniagua- Jorge Pirola- Geronimo de Amenabar- Josef de Migelperizena- En el Pueblo y Aciento y mineral de Yngaguasi, en quince dias del mez de octubre de mil setecientos setenta y siete años. Su merced el Señor Don Josef Maria de paniagua Cosio, y Teran, Comandante de Caballeria, Teniente de Capitan General, Juez de Vienes de difuntos, alcalde maior de minas y Registros, Juez Pribatibo de penas de Camara, de Comisos, y alcabalas, Corregidor y Justicia maior por $\mathrm{Su}$ magestad de esta Prouincia de Atacama su termino y jurisdiccion Juez en estos autos . En prosecucion

\section{Foja 29v}

de esta Ynformacion Sumaria hizo comparecer ante si y testigos a Don Antonio Borque, natural de los Reynos de España, en el de Castilla recidente en este Aciento, de quien su merced recibio Juramento que lo hizo a Dios Nuestro Señor y una Señal de Cruz se- 
gun derecho, en cuio cargo cargo prometio decir verdad, en todo lo que supiere y le fuere preguntado, y siendolo al tenor de las preguntas que constan de la instruccion de estos autos a foxas beinte y tres dada por el Señor fiscal que hizo la parate de Su magestad siendo Oydor,. A la primera pregunta dijo: que aunque estubo en este mineral quando en el se sucito el tumulto, y alsamiento que los Yndios de el perpretaron contra los Españoles que hauia aqui, en aquel entonses, no lo presencio el declarante, por haberse hallado en la ocacion, en el paraje que llaman, el agua Salada, que dista como tres quadras

A la segunda pregunta dijo: que oyo decir que con motibo de hauer puesto Don Domingo Chabes, el citado dia de Carnestolendas, una Vandera o gallardete colorado de Sarguilla encima de la puerta de su casa, como es costumbre en barias partes tales dias de Carnabal, para serciorar a todos, que ay baile o corrida de Pato, esto junto con barias noticias que tubieron los Yndios de algunos chasquis que hauia despachado aqui el General Corregidor de esta Prouincia Don Francisco Argumanis, entraron en sospecha

Foja 30r

y dio motibo a la probocacion, y tumulto que dichos Yndios emprehendieron

A la tercera pregunta dijo: que no sabe que los yndios hubiesen sido inducidos por perzona alguna para tal atentado

A la quarta pregunta dijo: que el martes de Carnastoledas, subio el declarante de estas minas, y estando comiendo en la casa de Martin Dias, con el, Don Antonio Contreras, Don Juan Antonio Mendez, que ya es difunto, y Don Manuel Luengo: los mando llamar Don Juan Bautista Miner, y le respondieron que si no corria prieza irian despues; que les bolbio a llamar al instante, con tro recado, que importaba fueren luego. Que con efecto se lebantaron todos y caminando para la Casa de dicho Miner se enderesaron para la de Chaves, donde supieron estaba, y dibisando a Alejo Ventura por detras de la capilla, segunda, que era entonses, lo fueron a encontrar, y con motibo de hauer la mañana de este dia corrido Don Domingo Chaves desde su tienda a un Yndio muchacho que le fue a comprar una solapa y por no sabe que motibo fribolo, tubo la osadia de tirar sela a la cara al tal Chavez, viendo el declarante y los demas, dos ruedas de mucha copia de Yndios, que abria como ochenta o ciento, sin otros muchos que miraban dispersos: le dijeron al Alejo Ventura, que se dibirtiese, y sosegasen, sin que resultase ninguna historia, a que respondio el tal Alejo que no abria nada. En cuio acto se llego un Yndio por detras llamado Diego Siaris, y les dijo a todos los cinco Españoles, con el declarante

Foja 30v

que ellos tenian la culpa; por lo qual Don Antonio Contreras, saco un cuchillo, y le tiro un apuñalada en un brazo, y pretendiendo asegundarle no lo alcanzo, y entonses dijeron los Yndios a ellos, empesando a pedradas contra los Españoles, quiens se encerraron todos en la casa de Don Domingo Chabes, y el declarante se aparto con Martin Diaz, tirando cada uno por su lado: pero viendo el que declara que toda la turba de Yndios, avia cargado a la casa del dicho Chaves donde estaban los Españoles, retrocedio por otra parte, asi por ber en lo que paraba el lanse, pues los Yndios empesaron a destechar la Casa, como por si en tal conflicto serbir de amparo a la mujer del dicho Charves que estaba dentro de la Casa: en cuia ocacion vio ir huyendo a Don Juan Bautista Miner y otros, y los Yndios todos corrieron tras de Don Domingo Chaves, quien refugiandose en una casa lo cercaron y dijeron los Yndios, pegarle fuego ay. Y entonses Alejo Ventura llamo al que declara, y le rogo tubiese cuidado con la Casa del dicho Chaves, que la puerta de Calle estaba hecha pedazos. En esta ocacion vio el declarante venir corriendo al dicho Chabes huiendo de los Yndios que lo hauian querido quemar, y de tanta sangre como bertia, y una pedrada que le tiro uno de tantos Yndios que le seguian caio en el suelo como muerto, y se le aserco un Yndio con una piedra grande a darle en la Cabeza; para acabarlo de matar y Don Pedro Hidalgo

\section{Foja 31r}

que estaba junto al que declara, le dio un grito al Yndio, con lo que el, no le acabo de quitar la vida; en cuia ocacion llego un mulato, nombrado el dorado, y lebanto al referido Chabes, sobre llebandolo, y cubriendole por las muchas piedras que tiraban los Yndios, quienes alla lejos donde llaman la Vanda lo mandaron amarrar. Y entonses el que declara, fue a la Yglecia y saco la Ymajen de Nuestra Señora de Loreto, para apaciguar el tumulto, $\mathrm{y}$ diciendole todos se quitase con la virgen, porquer con virgen y todo hauianle haser lo mismo con el; le quiatron al declarante la Ymagen, y el bolbio a la casa del tal Chavez: Que despues, los Yndios mandaron amarrar al referido Chabes estando tan herido como 
queda dicho, y con motibo de hauer salido herido entre Cuero y Carne un Yndio, quando los Españoles se hisieron lugar con bocas de fuego, para salir huyendo de la casa donde se enserraron viendo la perfidia de los naturales de estar destechando la Casa con el fin de acabarlos expresaron todos los Yndios, que si el Yndio herido moria hauian de matar luego al dicho Chaves

A la quinta pregunta dijo: que estaba el declarante en los valles, en la ocacxion que llego a este mineral el Corregidor Argumanis, y no supo lo que paso, pero oyo decir, que los Yndios se hauian ausentado todos llebandose de este mineral a todas as mujeres españolas, y los Españoles retirandose

Foja 31v

detras de un cerro o quebrada, para que quando vieniese su Corregidor, no tubiese con quien tratar ni justificar nada de lo acahesido. Y añade que el Cura Don Miguel Geronimo de Olmedo, escribio una carta a Alejo Ventura ordenandole que echase de este haciento, a Don Domingo Chaves, y todos los Españoles sin dejar uno, y que se fiasen en su braso y empeños que tiene en Chuqisaca, que el, los sacaria siempre vien Y que despues los indujo a todos, con el Casique Gouernador, a que echasen una derrama prorrateandose todos, hasta los Casiques cobradores, a quatro pesos cada uno, para seguir el pleito induciendolos con sus palabras; de que el los sacaria de todo el lebantamiento, sin castigo alguno, cuia cantidad de plata se la entrego el Casique Don Agustin Victorio Ramos al dicho Cura, y paso de dos mil pesos, todo lo qual consta de publico y notorio, publica voz, y fama, en toda la Prouincia, y este Mineral, por estarlo bosiferando publicamente, los Casiques cobradores de tributos que contribuieron quatro pesos cada uno diciendo que, que, se a hecho mas de dos mil pesos que han dado al Cura de Atacama para el pleito, y que es lo que hasta ahora a hecho por elllos en tres años. Que es todo lo que sabe ha visto, y oydo decir, y lo que puede decir en cargo del juramento que fecho tiene, y la verdad en que se afirmo y ratifico siendole leyda esta su declaracion que no le tocan las Generales de la ley

\section{Foja 32r}

que es de edad de treinta y seis años, poco mas o menos, y lo firmo con su merced, y los testigos con quien actua judicialmente a falta de Escribano Blas Lopez de Picod- En el Aciento y mine-

ral de Yngaguasi, Jurisdiccion de la Prouincia de Atacama en treinta y un dias del mez de octubre de mil setecientos setenta y siete años. $\mathrm{Su}$ merced el señor Don Josef Maria de Paniagua Cosio y teran Comandante de Caballeria, Teniente de Capitan General, Juez de Vienes de difuntos, Alcalde maior de minas y Registros, Jues Pribatibo de penas de Camara, de Comisos y alcabalas, Corregidor y Justicia maior por $\mathrm{Su}$ magestad de esta Prouincia su termino y Jurisdiccion dijo que respecto de estar su merced entendiendo en la pasificacion del tumulto perpretado por esta Prouincia en este mineral: por el Real despacho que se le ha remitido a dicho fin por su Alteza los Señores Precidente y Oidores de esta Real Audiencia de la Plata su fecha a catorce de junio del presente año, como consta de estos autos, y Real Provision en que se halla incerto un Ynforme hecho a dicha Real Audiencia por el Teniente de Ynfanteria de los reales ejercitos General Don Francisco de Argumaniz Fernandez Corregidor que fue de esta dicha Prouincia antesesor de Su merced quien macula y calumnia en el al Doctor Don Miguel Geronimo de Olmedo Cura de la Doctrina de Atacama, cabeza

\section{Foja 32v}

de esta referida Prouincia, atribuiendole a su direccion, y maximas, la sublebacion, que queda exprezada, lo que dio merito, a la resolucion tomada por su Alteza, y dicho Señores en el auto que acordaron, en fuerza de lo que expuso, y pidio, el señor fiscal, y documentos que se tubieron a la vista, mandando en treinta de octubre del año pasado de setecientos setenta y cinco se le notificase e hiziese saber al dicho Doctor Olmedo que en el termino de la ordenanza presisamente comparesiere en dicha Corte y Real Audiencia, para los efectos que hubiese lugar en derecho probeiendo y ordenando en dicho auto se librase otra Real prouicion de ruego, y en cargo, al Venerable Dean y Cauildo de dicha Ciudad de la Plata se de vacante a fin de que probeises perzona Eclesiastica, que administrase los Sacramentos, en dicho Beneficio, en el interin que por dicha Real Audiencia, se daba la prouidencia mas conforme que hubiese lugar en derecho. Atento a todo lo qual, ya que dicho Cura Don Miguel Olmedo no solamente ha incurrido, en el criminoso atentado de hauer avierto en su casa este real Despacho, que su Alteza remitio a su merced, serrado dandoselo avierto, y sin cubierta, al Casique Gouernador, para que lo trajese a este jusgado, como se adbierte en el decreto de 
obedecimiento de el, en que se expone hauerlo demonstrado, y guardado el Casique hasta llegar a este haciento: sino que hasta oy se halla en esta Prouincia

Foja 33r

administrando y sirbiendo el Beneficio y $\mathrm{Cu}$ rato de Atacama, en consorcio de su quadjutor, sin hauer patentisado a su merced, la Superior orden de Su Alteza, que para ello debia hauer obtenido; llegandose a esto, que desde el dia beinte y tres de septiembre del mez proximo pasado se halla viviendo en este haciento, y mineral solicitando testigos que depongan a su fabor, y en contra de los Yndios naturales, que componen esta Prouincia de $\mathrm{Su}$ magestad (que Dios Guarde) rogando y buscando, quien igualmente lo ejecute de Prouincia ajena, hasta hospedarlos en su Casa, como lo fue Don Bernardo de Cordoba becino del Valle de San Carlos de la Prouincia del Tucuman, quien hizo la primera declaracion que se registra en estos autos: de todo lo qual se biene en pleno conosimiento que no sera dable poderse justificar lo resuelto y mandado por Su Alteza dicha Real Audiencia de la Plata, en sus autos prespcrptos, que aparecen en dicho Real Despacho; y mucho menos absolber, las cinco preguntas que se contienen en la Ynstruccion dada por el Señor fiscal que hizo la parte de Su magestad, siendo oydor para la aberiguacion, de todo lo acahesido segun consta de ella misma en este proseso de foxas beinte y tres. En cuia virtud, y para poder plenamente cumplir, y justificar lo resuelto, y mandado en dicho Real despacho; y que los declarantes puedan exponer libre y claramente la verdad sin que sean inducidos

Foja 33v

ni aconsejados, por perzona alguna, y menos por dicho Cura como se prebiene en el derecho, para que se evite todo obice, contra qualquiera de las partes cauzadas: maiormente quando sin embargo de hallarse su merced actuado de la materia haciendole cargo al dicho Cura, de algunas cosas presedidas en este haciento, y Prouincia, le exprezo no tener en el dia obligacion ni cargo alguno en ella, por ser solo un clerigo coadjutorado. y refleccionando su merced, sobre lo dicho y demas que queda expuesta, y que quando a un Cura Doctrinero se le probe de coadjutor, por un Tribunal Superior, es sin duda por particular cauza, y motibo, que para el caso a ocurrido, y no puede bolber a entrar en el Beneficio de su Curato sin expecial orden del Regio Tribu- nal que lo ceparo. Visto todo lo qual exprezo $\mathrm{Su}$ merced, deuia de manda y mando se le notifique al citado Doctor Don Miguel Geronimo de Olmedo, Cura Doctrinero del Pueblo de Atacama, Cabeza de esta dicha Prouincia, que se halla en este haciento y mineral: salga de el, y toda ella, y su jurisdiccion presisamente dentro del termino de tres dias, pasando a presentarse ante $\mathrm{Su}$ Alteza los Señores Precidente y oidores de la Real Audiencia de la Plata, como se prebiene, y manda en el auto acordado, expedido a dicho fin: estando de manifiesto en aquella Corte, a las resultas de los que sentensiase dicha Real Audiencia segun se halla ordenado

Foja 34r

y resuelto por ella, con apercevimiento, que de lo contrario, pasado dicho termino, se dara parte a dicho Real Tribunal, con tanto de este Auto a efecto de que se cerciore su alta integridad, de como se cumplen sus mandatos, y le parara el perjuicio que dichos Señores hallaren mas conforme a derecho: haciendosele al mismo tiempo por este Jusgado el correspondiente Ynforme con testimonio con testimonio a su prelado, el Ilustrismo Señor Arzovispo de Chuquisaca, para que le conste los procedimientos, de dicho Eclesiastico, Cura de Atacama. Para lo que y haserle saber, este auto leyendoselo de verbo adberbun, dio $\mathrm{Su}$ merced, la Comision bastante, y en derecho nesesaria, a Don Justo Nauarro, recidente en este haciento, quien con cinco testigos que le han de acompañar sentara la diligencia, en estos autos a continuacion. Asi lo probeio mando y firmo Su merced actuando judicialmente, con testigos a falta de Escribano, Publico ni Real _ Don Josef Maria Paniagua de Paniagua y Cosio- Blas Lopez de Picod- Jacinto

Notifica Fernandez- En dicho haciento y mineral. Luego Yncontininti, dicho dia mez y

cion año Yo Don Justo Nauarro, en virtud de la Comision a mi dada; notifique e hize saber el auto antecedente leyendoselo de verbo adverbun a Don Miguel de Olmedo, Cura de Atacama, en su persona que lo oyo y entendio. $\mathrm{Y}$ para que conste lo firme con los testigos que me acompañaron a falta de escribano Justo Nauarro- Blas Lopez

Foja 34v

Auto de Picod- Manuel Luengo- Jacinto FernandezEn el Haciento, y mineral de Yngaguasi Jurisdiccion de la Prouincia de Atacama en dies dias del mez de nouiembre de mil setcientos setenta y siete años. Su merced el 
señlor Don Josef Maria de Paniagua, Cosio, y Teran Comandante de Cablleria Teniente de Capitan General, Juez de Vienes de difuntos, Alcalde maior de minas y Registros Juez pribatibo de penas de Camara de Comisos y alcabalas, Corregidor y Justicia maior por $\mathrm{Su}$ magestad de esta dicha Prouincia su termino y Jurisdiccion. Hauiendo visto estos autos, y la notificacion hecha a Don Miguel Geronimo de Olmedo del auto que antecede probeido en treinta y un dia del mez proximo pasado de ocutbre; en virtud de lo resuelto y mandado por el Superior auto de treinta de octubre del año pasado de setcientos setenta y cinco que consta del Real despacho librado por los Señores Precidente, y Oidores de la Real Audiencia de la Plata que no ha querido obedecer, aun siendo pasado el termino con tanto exseso, atenido al fuero Eclesiastico que gosa. Dijo Su merced: que para proceder conforme a lo determinado por dicha Real Audiencia segun derecho en la Sumaria Ynformacion que se ordena, y para precaber maiores inconbenientes que pueden resultar por los Consejos de dicho Cura, y sus inducciones, asi los Españoles, como a los Yndios deuia de mandar, y mando su merced, se les abise a unos, y otros en general

\section{Foja 35r}

concurran a estas Casas de Cauildo, y hasiendoles saber lo mandado por dicho Regio Tribunal y la notificacion hecha en su consequencia a dicho Cura Olmedo, se les notifique, y aperciba a los Españoles bajo la multa de cinquenta pesos, aplicados por mitad para la Camara de Su magestad y gastos de justicia de esta Prouincia: y a los Yndios de prision, y embargo remitiendo los presos a la Real Carcel de Corthe de dicha Real Audiensia, el que puciere los piez en la Casa del citado Eclesiastico, hablare con el, o le solicitare para tratar sobre lo acahesido en este mineral, o So color, con otro pretexto alguno para de esta forma poderles tomar sus declaraciones imparciales sin agrauio de parte. Y respecto de hauerle prebenido $\mathrm{Su}$ merced al casique Don Agustin Victorio Ramos, le apronte los Salarios o parte de ellos que tienen ofrecidos en dicha Real Audiencia, para el Juez que biniere a esta prouanza por su memorial de foxas ciento treinta y seis segun consta del Real Despacho a que le trajo la respuesta, delante de cinco testigos españoles, que le hauia respondiddo su Cura no queria entregarle ni un peso de la derrama que hauian puesto en su poder para el Seguimiento de este pleito. $\mathrm{Si}$ ante todas cosas no le entregaba dicho General el despacho de la Real Audiencia con todo lo actuado sobre la materia se entienda dicha probanzas sobre este asunto tambien, para que conste en stos autos y obre los efectos que hubiere lugar en derecho. Asi lo probeio, mando, y firmo

\section{Foja 35v}

$\mathrm{Su}$ merced actuando judicialmente con testigos a falta de Escribano - Don

Notifica Josef Maria Paniagua y Cosio- Justo NauarroJacinto Fernandez- Luego

cion Yncontinenti Yo el dicho General Corregidor y Justicia maior por Su magestad d esta dicha Prouinsia, Jues en estos autos. en virtud de lo por mi manadado en el que antecede, ordene a los Alcaldes prebiniesen a todos de mi orden el primer dia de fiesta despues de misa concurriesen a estas Casas, y estando en ella les hize entender lo resuelto y manadado en el antecedente auto, y para que conste lo pongo por diligensia, que firme con testigos a falta de Escribano - Paniagua- Jacinto Fernandez- Blas Lopez de

declara Picod- En el haciento y mineral de Yngaguasi Jurisdiccion de la Prouincia de Atacama en onse dias del mez de Nouiembre del año de mil setecientos setenta y siete $\mathrm{Su}$ merced el Señor Don Josef Maria de Paniagua Cosio, y Teran, Comandante de caballeria Teniente de Capitan General, Corregidor, y Justicia maior por $\mathrm{Su}$ magestad de esta dicha Prouincia y Juez en estos autos. Dijo: que en atension a hauer llegado aqui, el dia de ayer despues de puesto el sol, un Comicionado de los Oficiales Reales de Potosi, quien a las ocho de la noche cargado de armas blancas, y de fuego con otras tres perzonas Españolas en los mismos terminos, y msa de ciento, y cinquenta Yndios con palos, y piedras en las manos que salieron todos de la Casa de

\section{Foja 36r}

dicho Cura, donde se alojo el citado Comiconado le notificase a su merced un auto de prision, y embargo de Vienes de orden de dichas cajas, y aunque le hizo presente este Real despacho de Su Alteza, en que de su Superior orden estaba ocupado en asunto tan pribilejiado, y de la primera atension: a que respondio el referido Comicionado no obedecia a dicha Real Audiencia, ni a otro ninguno Superior Tribunal, y que por fuerza debia cumplir su Comicion ejecutando a lo que hauia benido. Por lo que refleccionando $\mathrm{Su}$ merced, las perjudiciales consequensias que de ello podian resultar a la Real Corona, con otra nueba Sublebacion, que se estaba 
notando en el temerario atentado, y semblantes de su numeroso concurso, se precabio $\mathrm{Su}$ merced de prudencia, en cuia virtud, y de lo que queda expuesto dijo: deuia de mandar, y mando, se suspenda por ahora esta Sumaria y Justificacion, en tregandosele a perzona de la satisfacion de su merced, para que se la pase a la Villa de Potosi, donde esta proximo a Caminar por los motibos, y violencia que deja referidos, para de esta forma obiar lo que la malicia pudiera executar. Y sacandose los testimonios que combengan para los efectos que se ordena, en el auto probeido en treinta y un dias del mez de octubre del presente, se da parte a dicha Real Audiensia. Asi lo porbeio mando y firmo Su merced actuando Judicialmente con testigos

Foja 36v

a falta de Escribano - Don Josef Maria de Paniagua- Jacinto Fernandez-

Ymforme Blas Lopez de Picod= Por el Real despacho que acompaño, y se sirbio Vuestra Alteza, dirigirme en dies y seis de Junio del proximo año pasado de setecientos setenta y siete, para que practicase en mi Prouincia de Atacama, las diligensias mas prudenciales, y conducentes a la Pacificacion del tumulto, perpetrado en ella, el año de setecientos setenta y cinco recibiendo la correspondiente Ynformacion; se impondra su Savia integridad, de todo lo actuado, y lo que logre adelantar a fabor de vuestra Real Corona. Y hauiendo acaesido el inopinado caso, y escandaloso atentado que consta del ultimo auto que probey, en onse dias del mez de nouiembre del citado año que espira; no es indispensable dejar de remitirlo todo a vuestro Real acuerdo de Justicia; para que la recta que administra se serciore del justo motibo, que dio merito a detenerme, y no poder pasar a las Reales Cajas de Potosi, a evaquar los ultimos requicitos que me restaban instruiendo en aqeullos oficios, y Cauildo, las fianzas que di en Lima, y recepcion al uso, y exersicio de mi empleo que el de aquella ciudad ejecuto de Superior orden de Su excelencia

\section{Foja 37r}

[dos lineas borrosas]

de la primera atension, a tenido por combeniente pasarla a manos de Vuestra Alteza a fin de que no se dibulguen sus pruebas que se miran muy al principio, y que enterado vuestro Regio Tribunal, me mande debolber el proseso para completar su plena justificacion, o lo que sea vuestro Real agrado $=$ Nuestro Señor Guarde la Catolica Real
Perzona de Vuestra Alteza, los muchos años que estos Reynos nesecitan, para su total Paz, y conserbacion. Plata beinte y dos de febrero de mil setecientos setenta y ocho- Don Josef Maria de Paniagua, y Cosio= Plata y febrero beinte y tres de mil setecientos setenta y ocho= Autos al Real Acuerdo- Una rubrica- Probeiron y rubricaron el auto de suso los Señores Precidente y oidores de esta Real Audiencia y fue Juez el Señor Doctor Josef Lopez Lisperguer, Oydor en la Plata en el dia mez y año de su fecha- Don Sebastian Antonio

Auto Toro- Vistos Guardese lo porbeido oy dia de la fecha, y en su conformidad debuelbase original este expediente al Corregidor de la Prouincia de Atacama, para que continue, y adelante la aberigucion de los autores del tumulto y demas diligencias que se le tienen ordenadas en las Reales Prouiciones que para el efecto se libraron - Una rubrica

foja $37 \mathrm{v}$

Probeiron y rubricaron el auto de Suso los Señores Precidente y Oidores de esta Real Audiencia, y fue Juez el Señor Doctor Don Josef Lopes Lisperguer Oydor en a Plata en seis de marzo de mil setecientos setenta y ocho años= Escrito precente el Señor fiscal- Don Sebastian Antonio Toro- Muy Poderoso Señor - Juan de Cabrera y Urriola en nombre del Doctor Don Miguel Olmedo, Cura propio del Beneficio de Atacama en la Prouincia de este nombre, y en virtud de su poder que tengo presentado en esta Real Audiencia, como mejor proceda de derecho ante la justificacion de Vuetrsa Alteza paresco y Digo: que ha llegado a mi noticia, que en la cauza que a seguido el Corregidor de aquella Prouincia, contra los Oficiales Reales de Potosi, entre otras cozas se ha prouidensiado se libre Real Prouicion de ruego, y encargo al muy Reberendo Arzobispo para que en vista de las diligensias actuadas por el ya citado Corregidor tome las prouidencias que fuere de su Pastoral celo, para que el citado Doctor Olmedo se retire de la Prouincia a fin de que sin tropieso se pueda proceder a la aberiguacion de los autores del tumulto que se dice $\mathrm{Y}$ respecto de que a nombre de dicho Doctor tengo que deducir lo combeniente a su derecho

Foja 38r

se ha de serbir la justificacion de Vuestra Alteza mandar se me entreguen los contenidos autos por el termino ordinario vajo de conosimiento por tanto - A vuestra Alteza pido y suplico asi lo probea, y mande que sera justicia juro en anima de mi parte lo nesesario en derecho y para ello etcetera- Juan de Ca- 
brera y Urriola- En la Plata en doce de marzo de mil setecientos setenta y siete años: ante los señores Precidente y Oidores de esta Real Audiensia en la de relaciones se presento esta Petision- Los dichos Señores mandaron traer los autos a la Real Sala. Don Sebastian Antonio Toro. Vistos esta parte ocurra al Muy Reberendo Arzovispo en cuio Jusgado usara de sus defenzas- dos rubricas. Probeieron y rubricaron el auto de Susos los señores Precidnte y Oidores de esta Real Audiensia y fiueron Juezes los Señores Doctores Don Josef Lopes Lisperguer, y Don Ramon de Riuera Oydores en la Plata en trece de marzo de mil setecientos setenta y siete años. Don Sebastian Antonio Toro- En la Plata en Veinte y seis de dicho mes y año notifique el auto antecedente a Juan de Cabrera y Urriola, Procurador en nombre de su parte de que doy fe - Toro- Muy Poderoso Señor - Don Josef Maria de Paniagua, Cosio, y Teran, Comandante

Foja 38v

de Caballeria, Teniente de Capitan General, Corregidor y Justicia maior por Su magestad de la Prouincia de Atacama. En los autos que sigo sobre la restitucion del despojo de dicha Prouincia, contra los Oficiales Reales de Potosi, y Don Mateo Castaño, nombrado de Corregidor interino para dicha mi Prouincia por el exselentisimo Señor Don Pedro Ceballos, Virrey que fue de Buenos Ayres, y mandado continuar sin audiencia mia, citacion ni conosimiento de cauza, por el actual excelentisimo Señor Virrey con lo demas deducido sobre la materia como mejor proceda de derecho. Digo: que respecto de estar mandado por vuestra Alteza se de quenta a Su magestad, y al Superior Gouierno de este Distrito, de las prouidensias tomadas en esta cauza, con testimonio integro de los autos, conviene a mi derecho se mande agregar testimonio de las diligensias que practique, en virtud de la Real Prouision, que me dirigio Vuestra Alteza, sobre la aberiguacion de los complices en los tumultos anteriores de aquella Prouincia, y sobre la Pacificacion de ella: cuio cumplimiento fue, el primer objeto de mi cuidado, luego que ingrese a ella, como lo califica el expediente original que anteriormente manifeste a Vuestra Alteza y ahora nuebamente presento, para que se mande sacar, y agregar testimonio

Foja 39r

debolbiendome el original- A vuestra Alteza Suplico, y ppido, que hauiendolo por manifestado, se sirba prober, en lo demas, segun llebo exprezado jurando lo nesesario, y para ello etcetera- Josef Maria de Paniagua y Cosio $=$ Plata y Abril dies y nuebe de mil setecientos setenta y nuebe- Agreguese el testimonio que esta parte expresa, el que debera sacarse con citacion, y debolbersele el original al presentante- Una rubrica- Probeio y rubrico el decreto antecedente su Señoria el Señor Doctor Don Pedro Antonio de Zernadas Bermudes del Consejo de $\mathrm{Su}$ magestad, su oydor y Alcalde de Corthe de esta Real Audiensia y Juez Semanero en ella, en

Citacion el dia mez y año dse su fecha. Don Sebastian Antonio Toro- en dicho dia mez y año. Yo el Escribano cite con el escrito, y decreto antecedentes a Juan Josef de Saabedra Procurador en nombre de su parte de que doy fe. ToroConcuerda este traslado con el espediente original de su conte[nido] con el que corregi y conserve a que en caso nesesario me refire Y para efecto de remitir al excelentisimo Señor Virrey de estos Reynos os hise sacar el presente en la Plata en dos de ma[yo] de mil setecientos setenta y nuebe años $=$ Derecho rubrica Sebastian Antonio Toro.

\section{INDICE ONOMASTICO}

\author{
Amenábar, Gerónimo de f 24v, f 25v, f 27r, f 29r \\ Araya, Gregorio (propio) f $6 r$ \\ Argumanis Fernández, Francisco de (Corregidor de la Pro- \\ vincia de San Pedro) f 1v, f 2r, f 8v, f 9v, f 10v, f 11v, f \\ $12 \mathrm{v}, \mathrm{f} 13 \mathrm{v}, \mathrm{f} 14 \mathrm{r}$, f $16 \mathrm{r}$, f $18 \mathrm{r}$, f $21 \mathrm{r}$, f $23 \mathrm{v}$, f $28 \mathrm{v}$, f $29 \mathrm{v}, \mathrm{f}$ \\ $31 \mathrm{r}, \mathrm{f} 32 \mathrm{r}$ \\ Barela, Josef (cura) f $1 \mathrm{r}$ \\ Benabides, Ambrosio (coronel de infantería) f 17v, f $18 \mathrm{v}$ \\ Blanco Cruz, Juan f $13 r$ \\ Borque, Antonio f 25v, f 29v, f 32r \\ Cabrera y Urriola, Juan de f $37 v$, f $38 r$
}

Canisares, Josef (Oidor/fiscal de la Audiencia) f 1v, f $3 \mathrm{v}$, (comisionado) f 9r, f 10r, f 23v, f 26r

Carmona, Manuel Isidro (médico) f 19r

Castañares, Josef $\mathrm{f}$ 20r

Castaño, Mateo (Corregidor interino) f $38 \mathrm{v}$

Ceballos, Pedro (antiguo Virrey de Bs. Aires) f 38v

Contreras, Antonio (minero de Ingaguasi) f 15v, f 27v, f 28r, f 30r, f 30v

Córdova, Bernardo de (vecino del valle de San Carlos) f 26v, f 27r, f 33r

Chávez, Dionisio f $15 \mathrm{v}$ 
Chávez, Domingo (mercader en géneros) f 28r, f 28v, f 29v, f $30 r-v, f 31 v$

Díaz, Martín f 15r, f 30r, f 30v

Fernández, Jacinto f 25v, f 34r-v, f 35v, f 36v

González, Pedro Pablo (Escribano receptor del número de la R. Audiencia) f 6r

Hidalgo, Pedro f $30 \mathrm{v}$

Infante, Gil (escribano público) f 19r, f 20r

Irasmendi, Severo de (comisionado) f $3 \mathrm{v}, \mathrm{f} 8 \mathrm{v}$

Iribarren, Josef $\mathrm{f} 25 \mathrm{v}$

León de Ojeda, Nicolás f 17v, f 18r, f 20v, (Mastre de Campo) f $18 \mathrm{v}, \mathrm{f} 19 \mathrm{r}, \mathrm{f} 21 \mathrm{v}$

López Lisperguer, Josef (Juez Real Audiencia de la Plata), $f$ $2 \mathrm{r}$, f 10v, f $13 \mathrm{v}$, f $16 \mathrm{v}$, f $17 \mathrm{r}$, f $18 \mathrm{v}$, f 21 r, f $37 \mathrm{r}-\mathrm{v}$, f $38 \mathrm{r}$

López de Picod, Blas f 25v, f 32r, f 34r, f 35v, f 36v

Luengo, Manuel f 25v, f 30r, f 34v

Mallavia, Juan de (Gran Canciller) f $18 \mathrm{v}$

Mariano Ambrosio (indio) f 13v, f 16v

Matorras, Gerónimo (Gobernador del Tucumán) f 9v, f 13r

Mena, Philiberto f 17v, f 18r, f 19r-v, f 20v, f 21v

Méndez, Juan Antonio f 30r

Migelperizena, Josef de f 24v, f 25v, f 27r, f 29r

Miner, Juan Bautista f 15r-v, f 28r-v, f 29r, f 30r-v

Navarro, Justo (residente en el asiento de Yngaguasi) f 34r, f $35 \mathrm{v}$

Olmedo, Manuel (Miguel) Gerónimo de (Doctor, Cura de San Pedro de Atacama) f 4r, f 7r, f 9v, f 10r, f 13r, f 13v, f $14 v$, f $17 v$, f $23 v$, f $31 v$, f $32 r-r$, f $33 r$, f $34 r$, f $34 v$, f $37 \mathrm{v}$

Paniagua Cosio y Terán, Josef María (Corregidor de la Prov. de Atacama) f 21v, f 22r, f 24v, f 25v, f 26r, f 27r, f 29r, f 32r, f 34r, f 35v, f 36v, f 37r, f 38r, f 39r

Pinto, Pascual (indio) f 28v

Pirola, Jorge (vecino de Arequipa) f 27v, f 29r

Purulla, Valeriano (cacique cobrador) f $2 \mathrm{r}, \mathrm{f} 7 \mathrm{v}, \mathrm{f} 10 \mathrm{v}$

Quiñones, Ignacio $f 25 \mathrm{v}$

Ramos Mundaca, Josef (cacique principal) f $5 r$

Ramos, Agustín don (cacique y alcalde mayor de San Pdo de Atacama) f $1 \mathrm{v}$

Ramos, Agustín Victorio (Cacique principal del Pueblo de San Pedro de Atacama) f 7v, (Gobernador) f 14v, f 16v, f $17 \mathrm{r}$, f $18 \mathrm{v}$, f $22 \mathrm{v}$, f $24 \mathrm{r}$, f $25 \mathrm{v}$, f $26 \mathrm{r}$, f $31 \mathrm{v}$, f $35 \mathrm{v}$

Rioja Sinforoso, Josef de $\mathrm{f} 13 \mathrm{r}$

Rivera, Ramón de f 9v, f 12r, f 18v f 20v, f 38r

Saavedra, Juan Josef de (procurador) f $59 \mathrm{r}$

Siaris, Diego Martín (indio) f 10v, f 13v, f 14r, f 16r, f 16v, f $21 \mathrm{r}$, f $22 \mathrm{r}$, f $27 \mathrm{v}$, f $30 \mathrm{r}$

Tagle, Pedro de (Doctor y Juez de la Real Audiencia de la Plata) f 2r, f 10v, f 13v, f 16v, f 17r-v

Toro, Sebastián Antonio (Secretario Real Audiencia) f 2r, f $13 \mathrm{v}$, f $16 \mathrm{v}$, f $17 \mathrm{v}$, f $18 \mathrm{v}$, f $20 \mathrm{v}$, f 21 r, f 22 r, f 37 r, f $37 \mathrm{v}$, f $38 r$, f 39r.

Ventura, Alejo (indio) f 5r, f 10v, f 13v, f 14r, f 16r-v, f 21r, f $22 r$, f $28 v$, f $30 r-v$, f $31 v$

Vicente Domingo (alcalde de naturales) f $27 \mathrm{r}$

\section{INDICE TOPONIMICO}

Agua Salada (paraje) f 28v, f 29v

Arequipa (ciudad) f 27v

Atacama en todo el documento

Banda la (sector distante de 3 cuadras de Ingaguasi) f 31r

Buenos Aires f 38v

Calcachi, valle Jurisdiccion del Tucumán f 2r, f $3 \mathrm{v}$, f $8 \mathrm{v}$, f $28 \mathrm{v}$

Chiu Chiu f $5 \mathrm{r}$

Chorrillos los (paraje) f 9v, f 23v

Chuquisaca f $31 \mathrm{v}$, f $34 \mathrm{v}$

Ingaguasi (cerro de) f $2 \mathrm{v}, \mathrm{f} 3 \mathrm{v}, \mathrm{f} 9 \mathrm{r}$, (mineral y asiento) $\mathrm{f}$ $12 \mathrm{v}, \mathrm{f} 13 \mathrm{r}$, f 14r, (Nuestra Señora de Loreto) f 15v, f 20r, f $21 \mathrm{r}$, f $22 \mathrm{r}$, f $24 \mathrm{v}$, f $25 \mathrm{v}$, f $26 \mathrm{r}$, f $27 \mathrm{r}$, f $29 \mathrm{r}$, f $32 \mathrm{r}$, f $34 \mathrm{v}$, f $35 \mathrm{v}$
Lima f 23r, f 36v

Molinos los (paraje) f 20v

Navidad $f 7 \mathrm{v}$

Plata, de la f 9v, f 10v, f 11r, f 12r, f 13v, f 16v, f 17r, f 17v, f $18 \mathrm{v}$, f $20 \mathrm{v}$, f $21 \mathrm{r}$, f $22 \mathrm{r}$, f $24 \mathrm{r}$, f $25 \mathrm{r}$, f $32 \mathrm{r}-\mathrm{v}$, f $33 \mathrm{r}-\mathrm{v}$, f $37 r-v$, f $38 r-v$, f $39 r-v$

Potosí f 4v f 6r, f 7r, f 8r, f 25v, f 35v, f 36v, f 37v, f 38v

Ratones los (paraje y quebrada) f 26v, f $28 \mathrm{v}$

Salta f 3v, f 19r

San Carlos (valle) f 26v, f $33 r$

San Juan $f$ $7 v$

Tucumán f 3r-v, f 6v, f 9r-v, f 10v, f 11v, f 12r-v, , f 13r-v, f $18 r$, f 18 r, f $20 v$, f 21 r, f $23 v$, f $26 v$, f $28 v$, f $33 r$ 